\title{
CARACTERIZAÇÃO DE ISOLADOS DE Colletotrichum lagenarium, AGENTE CAUSAL DA ANTRACNOSE DAS CUCURBITÁCEAS
}

\author{
ANgelo Aparecido Barbosa SusSel
}

Dissertação apresentada à Escola Superior de Agricultura “Luiz de Queiroz”, Universidade de São Paulo, para obtenção do título de Mestre em Agronomia, Área de Concentração: Fitopatologia.

P I R A C I C A B A

Estado de São Paulo - Brasil Janeiro - 2005 


\title{
CARACTERIZAÇÃO DE ISOLADOS DE Colletotrichum lagenarium, AGENTE CAUSAL DA ANTRACNOSE DAS CUCURBITÁCEAS
}

\author{
ANgelo Aparecido Barbosa SusSel \\ Engenheiro Agrônomo
}

Orientador: Prof. Dr. NELSON SIDNEI MASSOLA JÚNIOR

Dissertação apresentada à Escola Superior de Agricultura “Luiz de Queiroz”, Universidade de São Paulo, para obtenção do título de Mestre em Agronomia, Área de Concentração: Fitopatologia.

P I R A C I C A B A

Estado de São Paulo - Brasil

Janeiro - 2005 
Dados Internacionais de Catalogação na Publicação (CIP) DIVISÃO DE BIBLIOTECA E DOCUMENTAÇÃO - ESALQ/USP

Sussel, Angelo Aparecido Barbosa

Caracterização de isolados de Colletrotrichum lagenarium, agente causal da

antracnose das cucurbitáceas / Angelo Aparecido Barbosa Sussel. - - Piracicaba, 2005. 68 p. : il.

Dissertação (Mestrado) - - Escola Superior de Agricultura Luiz de Queiroz, 2005.

Bibliografia.

1. Antracnose 2. Biologia molecular 3. Cucurbitácea 4. Fungo fitopatogênico - Morfologia I. Título

CDD 635.6

“Permitida a cópia total ou parcial deste documento, desde que citada a fonte - O autor" 
Se tiveres projetos para um ano, plante uma lavoura;

Se tiveres projetos para dez anos, plante uma árvore;

Se tiveres projetos para cem anos, eduque seus filhos;

Se tiveres projetos para mil anos, eduque uma nação.

(autor desconhecido) 


\section{AGRADECIMENTOS}

À Deus, pela vida.

À minha mãe Clarinda Barbosa, pelo amor, carinho, confiança e proteção que me concede desde seu ventre; e minhas mães de colo, pelo cuidado e atenção.

À meu irmão Rodrigo, pela amizade e cumplicidade desde nossa infância.

À minha grande família, pelo estímulo recebido estes anos todos.

À Mônica, pelo carinho, atenção e confiança.

Ao Prof. Dr. Nelson Sidnei Massola Júnior, pela orientação e ensinamentos.

Aos amigos Ricardo e Daniel, pela amizade, auxílio, e os bons momentos de convívio.

Aos colegas de Pós-Graduação, e de graduação, pela amizade e colaborações.

Aos Professores do Departamento de Fitopatologia, pelos ensinamentos e colaborações.

Aos funcionários do Departamento de Fitopatologia, pela amizade.

À ESALQ, pela oportunidade.

À CNPq, pela concessão da bolsa de estudos. 


\section{SUMÁRIO}

LISTA DE FIGURAS................................................................................. viii

LISTA DE TABELAS...................................................................................... iv

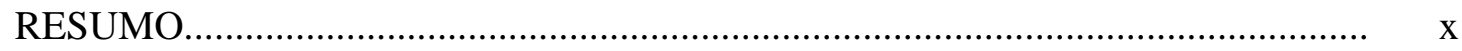

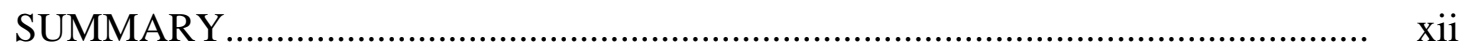

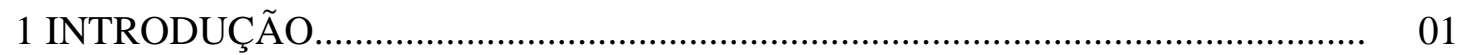

2 REVISÃO DE LITERATURA...................................................................... 03

3 CARACTERIZAÇÃO CULTURAL E MORFOLÓGICA DE ISOLADOS DE

Colletotrichum lagenarium................................................................................ 08

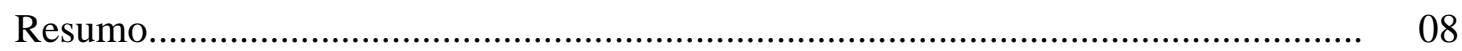

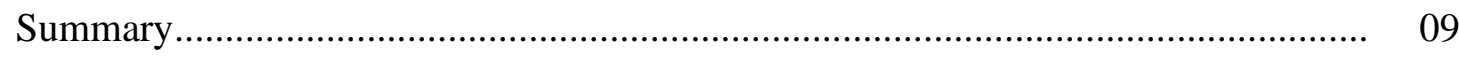

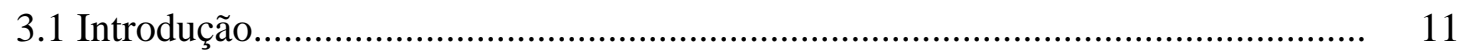

3.2 Material e Métodos..................................................................................... 13

3.2.1 Obtenção dos isolados..................................................................................... 13

3.2.2 Caracterização cultural de isolados de C. lagenarium......................................... 14

3.2.2.1 Crescimento micelial em diferentes meios de cultura..................................... 14

3.2.2.2 Formação de setores, topografia e coloração da colônia................................. 15

3.2.2.3 Esporulação em diferentes meios de cultura.................................................... 15

3.2.3 Caracterização morfológica de isolados de C. lagenarium................................. 16

3.2.3.1 Caracterização dos conídios........................................................................... 16

3.2.3.1.1 Caracterização quanto à forma dos conídios................................................ 16

3.2.3.1.2 Caracterização quanto às dimensões dos conídios....................................... 16

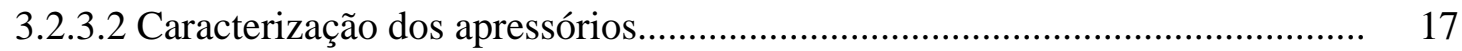

3.2.3.2.1 Caracterização quanto à forma dos apressórios............................................ 18 
3.2.3.2.2 Caracterização quanto às dimensões dos apressórios.

3.3 Resultados e Discussão

3.3.1 Coleção de isolados de C. lagenarium ....................................................... 19

3.3.2 Caracterização cultural de isolados de C. lagenarium..................................... 20

3.3.2.1 Crescimento micelial em diferentes meios de cultura.................................. 20

3.3.2.2 Formação de setores, topografia e coloração da colônia............................... 22

3.3.2.3 Esporulação em diferentes meios de cultura................................................ 26

3.3.3 Caracterização morfológica de isolados de C. lagenarium.............................. 28

3.3.3.1 Caracterização dos conídios......................................................................... 28

3.3.3.1.1 Caracterização quanto à forma dos conídios............................................... 28

3.3.3.1.2 Caracterização quanto às dimensões dos conídios..................................... 30

3.3.3.2 Caracterização dos apressórios.................................................................... 31

3.3.3.2.1 Caracterização quanto à forma dos apressórios............................................ 31

3.3.3.2.2 Caracterização quanto às dimensões dos apressórios.................................. 33

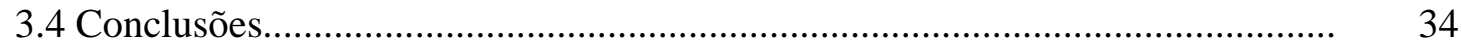

4 CARACTERIZAÇÃO PATOGÊNICA E IDENTIFICAÇÃO MOLECULAR

DE ISOLADOS DE Colletotrichum lagenarium................................................... 36

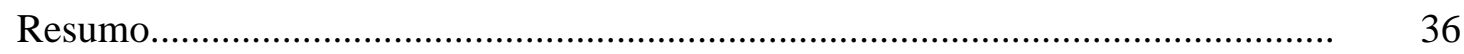

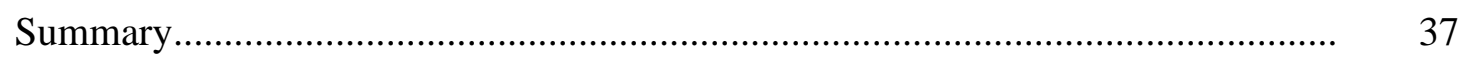

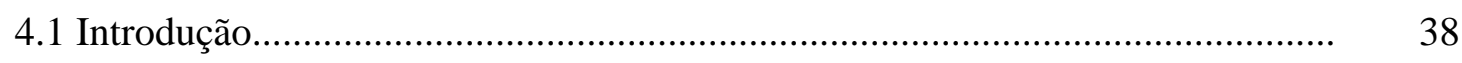

4.2 Material e Métodos....................................................................................... 41

4.2.1 Caracterização patogênica de isolados de C. lagenarium............................... 41

4.2.2 Identificação molecular de isolados de C. lagenarium.................................... 44

4.2.2.1 Extração de DNA........................................................................................... 44

4.2.2.2 Reação de PCR..................................................................................... 45

4.3 Resultados e Discussão...................................................................................... 46

4.3.1 Caracterização patogênica de isolados de C. lagenarium................................ 46

4.3.2 Identificação molecular.................................................................................. 52

4.3.2.1 Extração de DNA......................................................................................... 52

4.3.2.2 Reação de PCR............................................................................................ 52 
4.4 Conclusões.

54

5 CONCLUSÕES GERAIS.

56

REFERÊNCIAS BIBLIOGRÁFICAS. 


\section{LISTA DE FIGURAS}

Página

1 Produtos da PCR de 12 isolados de C. lagenarium, com o par de "primers" CoINT-ITS4 (M-marcador 1Kb; a-CH1; b-CH3; c-CH4; d-CL5; e-CL7; fCL22; g-PE3; h-PE4; i-AB2; j-MA1; k-MA3; l-ME3)..........................................
Produtos da PCR de 15 isolados de $C$. lagenarium, com os pares de "primers" ITS4-ITS5 (_-1) e CoINT-ITS4 (_-2) (M-marcador 1Kb; a-CH4, b-PE1, cPE3, d-PE4, e-PE5, f-CL5, g-AB274, h-AB1, i-AB2, j-AB3, k-ME1, lME2) 


\section{LISTA DE TABELAS}

Página

1 Relação de isolados de Colletotrichum lagenarium.

2 Médias de crescimento micelial diário de isolados de C. lagenarium nos meios de Aveia, meio BDA e meio V8.

3 Topografia, coloração micelial, cor de fundo de placa, formação de setores, presença e coloração da massa conidial de C. lagenarium, cultivados em meio de Aveia

4 Médias da esporulação de isolados de C. lagenarium meio de Aveia, meio BDA e meio V8.

5 Caracterização morfológica dos conídios de C. lagenarium.

6 Comprimento, largura, e relação $\mathrm{C} / \mathrm{L}$ dos conídios de isolados de $C$. lagenarium.

7 Caracterização morfológica dos apressórios de C. lagenarium.

8 Comprimento, largura, e relação C/L dos apressórios de isolados de C. lagenarium

9 Inoculação cruzada de isolados de C. lagenarium em pepino, melão, melancia, abóbora e chuchu.

10 Período de incubação, período latente e índice de crescimento de lesão de isolados de $C$. lagenarium. 


\title{
CARACTERIZAÇÃO DE ISOLADOS DE Colletotrichum lagenarium, AGENTE CAUSAL DA ANTRACNOSE DAS CUCURBITACEAS
}

\author{
Autor: Angelo Aparecido Barbosa SusSel \\ Orientador: Prof. Dr. Nelson Sidnei Massola Júnior
}

\section{RESUMO}

A antracnose, doença causada por fungos do gênero Colletotrichum, é uma das doenças mais importantes em muitas plantas cultivadas. Nas cucurbitáceas, como pepino, chuchu, melão e melancia, a antracnose é muito freqüente e causa prejuízos bastante elevados. O agente causal é o Colletotrichum lagenarium, que apresenta como sinonímias C. orbiculare e C. gloeosporioides f. sp. cucurbitae. O presente trabalho visa caracterizar cultural, morfológica e patogenicamente, e identificar molecularmente, os isolados de C. lagenarium, obtidos de plantas da família Cucurbitaceae. Os isolados foram obtidos através de isolamento de tecidos de plantas que apresentavam sintomas de antracnose. A caracterização cultural envolveu a avaliação do crescimento micelial, esporulação, coloração da colônia, topografia da colônia, formação de setores, presença e coloração de massa conidial. A caracterização morfológica compreendeu a 
avaliação das formas e dimensões dos conídios e apressórios. A caracterização patogênica envolveu a avaliação da virulência de todos os isolados em inoculações cruzadas com pepino, melão, melancia, abóbora e chuchu, além da avaliação do período de incubação, do período latente e do índice de crescimento da lesão. A identificação molecular compreendeu a análise de PCR, utilizando "primer” específico para $C$. lagenarium, para auxílio na identificação da espécie. Quanto à caracterização cultural, os isolados apresentaram uma variabilidade muito grande quanto à cor e topografia da colônia e formação de setores, contudo, quando analisada a coloração de massa micelial, nos isolados em que esta se fez presente, a coloração não apresentou grandes variações. Apesar da grande variação encontrada nos índices de crescimento micelial diário entre os isolados, não existiu grande variação para cada isolado quando se alterou o meio de cultivo. A esporulação não apresentou correlação com o crescimento micelial, e não constituiu um bom parâmetro para caracterização, devido à variação que apresentou tanto entre os isolados, quanto entre os meios de cultivo. Os conídios apresentaram formatos cilíndrico, clavado e levemente curvo, com dimensões variando de 2,25 a 6,38 $\mu$ m de largura e 5,34 a 15,73 $\mu \mathrm{m}$ de comprimento. Os apressórios apresentaram os formatos globoso, clavado e lobado, com dimensões variando de 5,54 a 8,68 $\mu$ m de

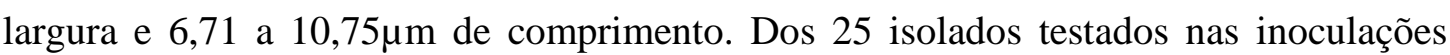
cruzadas, apenas 14 se apresentaram virulentos aos hospedeiros testados. Não foi encontrada correspondência entre a virulência do isolado e o hospedeiro, o local de coleta, suas características culturais ou morfológicas. Cada isolado apresentou um comportamento diferente perante os demais, quando se considerou a gama de hospedeiros a ele suscetíveis, e ao seu comportamento quanto aos períodos latente e de incubação, e ao índice de crescimento de lesão. O período de incubação variou de dois a sete dias, e período latente variou de três a nove dias. O índice de crescimento de lesão variou de 0,5 a 4,9mm/dia. Não foi observada correlação entre o período latente, o período de incubação e o índice de crescimento de lesão. Através da identificação molecular, cinco isolados puderam ser identificados pelo "primer” específico utilizado, contudo não foi encontrada correspondência entre a identificação molecular e as caracterizações cultural, morfológica e patogênica. 


\section{CHARACTERIZATION OF Colletotrichum lagenarium ISOLATES, CAUSAL AGENT OF ANTHRACNOSE OF CUCURBITACEA}

Author: Angelo Aparecido Barbosa Sussel

AdVISER: Prof. Dr. Nelson Sidnei Massola Júnior

\section{SUMMARY}

Anthracnose is one of the most important diseases of cucurbitaceous plants, causing severe damages to cucumber, chayote, melon, watermelon and pumpkin. The causal agent is Colletotrichum lagenarium (syn. C. orbiculare, C. gloeosporioides f. sp. cucurbitae). The objective of this work was to determine cultural, morphological and pathogenic characterization, and molecular identification of C. lagenarium, isolated from plants of the Cucurbitaceae family. The isolates used in this study were obtained through isolation from plants presenting symptoms of Anthracnose. The cultural characterization involved the evaluation of mycelial growth, sporulation, colony colour, colony topography, sectors formation, presence and colour of conidial mass. The shape and size of the conidia and apressoria were assessed to the morphological characterization. The pathogenic characterization involved the evaluation of the virulence of all isolates on cross inoculations with cucumber, melon, watermelon, pumpkin and chayote, evaluation of the incubation period, the latent period and the lesion growth. For the molecular identification PCR analysis was used, with specific 
"primer" for $C$. lagenarium, to assist the identification of the species. Colonies of all isolates presented great variability in color, topography, and sectors formation; however the color of the mycelial mass did not present great variations. Despite the great variation found in the daily micelial growth indices among the isolates, great variation for each one did not exist when the culture medium was changed. The sporulation did not present correlation with the micelial growth, showing a high variation among the isolates and the culture media. This later parameter was not useful for characterization. The conidia of the isolates were classified in the shapes cylindrical, clavate and slightly curved, with average dimensions varying from 2.25 to $6.38 \mu \mathrm{m}$ in width, and from 5.34 to $15.73 \mu \mathrm{m}$ in length. The apressoria had the shapes globose, clavate and lobed, with average dimensions varying from 5.54 to $8.68 \mu \mathrm{m}$ in width, and 6.71 to $10,75 \mu \mathrm{m}$ in length. From the 25 isolates tested in the cross inoculations, only 14 were virulent to the tested host plants. Correspondence was not found between the virulence of the isolates and de host plants origin, the local origin, and the cultural and morphological characteristics. Analyzing the variability of susceptible host plants, the inoculation and latent periods, and the lesion growth, each isolate showed a different behavior compared to the others. The incubation period varied from two to seven days, and the latent period varied from three to nine days. The lesion growth varied from 0,5 to $4,9 \mathrm{~mm} / \mathrm{day}$. It was not observed correlation between the latent and incubation periods, as well as in lesion growth. Five isolates were identified to the pair of primers used, although correspondence was not found among the molecular identification and the cultural, morphological and pathogenic characterization. 


\section{INTRODUÇÃO}

As plantas da família Cucurbitaceae suprem o homem com produtos comestíveis e fibras. Podem ser tão importantes como os cereais e legumes, e ocupam posição de destaque na dieta diária das regiões produtoras, constituindo-se como fonte de carboidratos e vitaminas; podem ainda ser empregadas na obtenção de utensílios domésticos.

O grupo que compreende as espécies de valor econômico desta família é constituído pelos gêneros: Citrullus - melancia (C. lanatus); Cucurbita - abóbora ( $C$. pepo) e moranga (C. maxima); Cucumis - melão (C. melo), maxixe (C. anguria) e pepino (C. sativus); e Sechium - chuchu (S. edule). As espécies Lagenaria siceraria, Luffa acutangula e Monordica charantia, respectivamente denominadas, cabaça (ou porongo), bucha e melão-de-são-caetano (ou goya), apesar de apresentar menor expressão econômica, são cultivadas em algumas áreas de agricultura tradicional (Queiroz, 1993).

A antracnose, causada por fungos do gênero Colletotrichum, é uma das doenças mais importantes em muitas plantas cultivadas. Nas cucurbitáceas, como pepino, melão, melancia, abóbora e chuchu, a antracnose é freqüente e causa prejuízos elevados. O patógeno afeta toda parte aérea da planta, em qualquer fase do seu desenvolvimento, causando desfolha precoce, com perda de vitalidade ou morte. Quando a doença incide sobre os frutos, os deprecia comercialmente, chegando a inutilizá-los para o consumo. Ocorre com maior severidade em clima ameno a quente, em épocas chuvosas. Nessas condições, quando não se faz um controle adequado, a doença pode provocar prejuízos de 100\% em pouco tempo (Agrios, 1997; Kurozawa \& Pavan, 1997; Thompson \& Jenkins, 1985; Sitterly \& Keinath, 1996). 
Patógenos do gênero Colletotrichum têm sido relatados parasitando mais de uma centena de plantas angiospermas (Alexopoulos et al., 1996). No caso da antracnose das cucurbitáceas, o agente causal é descrito na literatura como sendo C. lagenarium, que apresenta como sinonímia C. orbiculare e C. gloeosporioides f. sp. cucurbitae (Kurozawa \& Pavan, 1997, Correll et al. 1993; Sitterly \& Keinath, 1996).

Além dos métodos tradicionais de caracterização, análises cultural e morfológica, outros métodos vem sendo empregados recentemente com maior freqüência, entre eles a patogenicidade, os grupos de compatibilidade vegetativa, a análise isoenzimática, e os métodos moleculares, como RAPD e RFLP. Recentemente observa-se a necessidade de utilizar diferentes métodos de caracterização aliados aos métodos moleculares, principalmente devido a grande variabilidade genética encontrada dentro do gênero Colletotrichum. Esses trabalhos de caracterização trazem informações extremamente importantes para o conhecimento da variabilidade de determinadas espécies numa região, principalmente ao considerar que o conhecimento da variação da patogenicidade do patógeno deve ser o passo inicial de todo e qualquer trabalho de melhoramento genético de plantas visando a obtenção de variedades resistentes. Tais informações são de grande interesse quando se busca o controle das doenças causadas por essas espécies, seja por meio de resistência genética, uso de fungicidas ou práticas culturais.

O presente trabalho objetivou caracterizar os isolados de Colletotrichum lagenarium, oriundos de plantas da família Cucurbitaceae. Especificamente, objetivouse realizar a caracterização morfológica e cultural, buscando também identificar qual meio de cultura proporciona melhores condições para o crescimento micelial e esporulação do patógeno; realizar a caracterização patogênica e a identificação molecular da espécie C. lagenarium, entre os isolados. 


\section{REVISÃO DE LITERATURA}

As cucurbitáceas, com cerca de 90 gêneros e 800 espécies, estão entre as principais famílias de plantas cultivadas pelo homem. Apresentam grande importância do ponto de vista nutricional, cultural, e econômico, sendo muitas espécies, cultivadas e silvestres, utilizadas como parte da alimentação humana e animal (Minas Gerais, 1995).

O grupo que compreende as espécies de valor econômico desta família é constituído pelos gêneros: Citrullus - melancia (C. lanatus); Cucurbita - abóbora ( $C$. pepo) e moranga (C. maxima); Cucumis - melão (C. melo), maxixe (C. anguria) e pepino (C. sativus); e Sechium - chuchu (S. edule). As espécies Lagenaria siceraria, Luffa acutangula e Monordica charantia, respectivamente denominadas, cabaça (ou porongo), bucha e melão-de-são-caetano (ou goya), apesar de apresentar menor expressão econômica, são cultivadas em algumas áreas de agricultura tradicional (Queiroz, 1993).

A antracnose, doença causada por fungos do gênero Colletotrichum, é uma das doenças mais importantes em muitas plantas cultivadas. Nas cucurbitáceas, como pepino, chuchu, melão, melancia e abóbora, a antracnose é muito freqüente e causa prejuízos bastante elevados. Ocorre com maior severidade em clima ameno a quente, em épocas chuvosas. Nessas condições, quando não se faz um controle adequado, a doença pode provocar prejuízos de 100\% em pouco tempo (Agrios, 1997; Kurozawa \& Pavan, 1997; Thompson \& Jenkins, 1985; Sitterly \& Keinath, 1996).

Patógenos do gênero Colletotrichum têm sido relatados parasitando mais de uma centena de plantas angiospermas (Alexopoulos et al., 1996). Dentro desse gênero existe especialização para determinados grupos de hospedeiros, como por exemplo, $C$. graminicola, que ataca algumas Poáceas e C. lindemuthianum, patógeno do feijoeiro. No 
caso da antracnose das cucurbitáceas, o agente causal é descrito na literatura como sendo C. lagenarium, que apresenta como sinonímia C. orbiculare e C. gloeosporioides f. sp. cucurbitae (Kurozawa \& Pavan, 1997, Correll et al. 1993; Sitterly \& Keinath, 1996).

A patogenicidade específica a um determinado hospedeiro, ou grupo de hospedeiros, é constantemente utilizada em chaves de classificação para espécies de Colletotrichum (Baxter et al. 1983; Sutton, 1980). Contudo, em grande parte dos casos, a distinção entre espécies de Colletotrichum é feita com base em características morfológicas dos esporos e apressórios (Sutton, 1992). Sutton (1992), fornece descrição para cerca de 40 espécies, porém, esse autor afirma que a taxonomia de Colletotrichum é confusa e que, os critérios morfológicos são de pouco interesse quando informações mais detalhadas sobre um determinado isolado fitopatogênico são necessárias.

Na literatura é possível encontrar um número muito grande de trabalhos sobre a caracterização inter e intraespecífica de Colletotrichum. Os métodos utilizados para essas caracterizações são os mais variados, porém os mais freqüentes são a patogenicidade, análise isoenzimática e sensibilidade à fungicidas, além das tradicionais análises morfológica e cultural. Mais recentemente, um grande número de trabalhos utilizando marcadores moleculares, como RAPD e RFLP, têm sido desenvolvidos com essa finalidade. Esses trabalhos de caracterização trazem informações extremamente importantes para o conhecimento da variabilidade de determinadas espécies numa região, informações essas que são de grande interesse quando se busca o controle das doenças causadas por essas espécies, seja por meio de resistência genética, uso de fungicidas ou práticas culturais.

Atualmente são reconhecidos três grandes grupos do gênero Colletotrichum, baseados sobre as espécies C. gloeosporioides, C. acutatum e C. orbiculare, aos quais são agregadas demais espécies (Cannon et al., 2000). Dados moleculares e culturais indicam que muitas espécies do gênero Colletotrichum, particularmente aquelas que apresentam infecção intracelular hemibiotrófica, poderiam ser agrupadas junto à espécie C. orbiculare (Bailey et al., 1996; Sherriff et al., 1994; Sreenivasaprasad et al., 1996).

Por meio de testes de patogenicidade em ramos e frutos de macieira, Carvalho et al. (2000) caracterizaram isolados de C. gloeosporioides e C. acutatum, ambos 
associados à podridão amarga da maçã. As inoculações em frutos revelaram que as duas espécies são capazes de causar podridões, com algumas diferenças na sintomatologia. Porém, somente os isolados da espécie C. gloeosporioides foram patogênicos às folhas de macieira, sendo, portanto, essa a espécie causal da mancha de Glomerella em macieiras no Brasil. Num outro estudo, Bernstein et al. (1995), compararam setenta e dois isolados de Colletotrichum isolados de pêssego, maçã, pecan, morango e abacate. Os isolados puderam ser separados por coloração da colônia em dois grupos. O grupo que apresentou coloração rosada a alaranjada foi identificado como sendo C. acutatum e apresentou conídios com formato fusiforme, além de crescer em meio suplementado com benomyl. O outro grupo de isolados apresentou colônias acinzentadas, conídios com extremidades arredondadas e crescimento nulo em meio com benomyl. Este último grupo foi identificado como sendo C. gloeosporioides. Porém, apesar das diferenças descritas acima, testes de patogenicidade, em frutos destacados de pessegueiro, revelaram não ser possível distinguir os sintomas causados pelas duas espécies. Os autores concluíram que ambas as espécies ocorrem indistintamente causando doenças em pêssego, maçã e pecan. No Brasil, em dois estudos semelhantes à esse último (Goes \& Kimati, 1997a;b), encontraram resultados semelhantes. Os autores verificaram que, tanto C. gloeosporioides como C. acutatum, ocorrem naturalmente em plantas cítricas com sintomas de queda prematura dos frutos. Da mesma forma, os isolados de $C$. gloesporioides apresentaram coloração cinza, conídios ligeiramente maiores e crescimento rápido em meio de cultura. Os isolados de C. acutatum apresentaram coloração alaranjada, conídios menores e crescimento lento. Também houveram diferenças marcantes na forma dos apressórios entre as duas espécies. Além dessas diferenças culturais e morfológicas, os resultados dos testes de patogenicidade revelaram que somente os isolados de C. acutatum reproduziram os sintomas de queda prematura dos frutos.

Além da caracterização entre diferentes espécies de Colletotrichum, estudos de patogenicidade têm revelado também variabilidade dentro de uma mesma espécie, como é o caso do trabalho conduzido por Freeman et al. (1996). Trabalhando com isolados de C. gloeosporioides de amêndoa e de abacate, os autores realizaram inoculações 
cruzadas, em frutos destacados de ambas culturas. Os isolados provenientes de abacate provocaram intensidades semelhantes de doença em abacate e amêndoa, porém, os isolados de amêndoa foram bem menos agressivos quando inoculados em abacate. Isso revelou um certo grau de especialização nos isolados provenientes de amêndoa. Também no Brasil já se verificou variabilidade na capacidade patogênica de $C$. gloeosporioides. Furtado et al. (1999), estudando a variabilidade entre isolados de folha, painel, haste e frutos de seringueira, verificaram diferenças na patogenicidade quando foram inoculados discos de folíolos de seringueira em condições de laboratório. Da mesma forma, Assis et al. (2001), verificaram diferenças na agressividade entre seis isolados de C. gloeosporioides de frutos de mangueira por meio de testes de patogenicidade em frutos destacados das variedades Espada, Rosa e Tommy Atkins. Além disso, esses isolados se diferenciaram quanto ao crescimento micelial e esporulação quando diferentes fontes de carbono foram incorporadas ao meio de cultivo. O conhecimento da variação da patogenicidade deve ser o passo inicial de todo e qualquer trabalho de melhoramento de cucurbitáceas visando a obtenção de variedades resistentes a antracnose, e também a qualquer recomendação de rotação de culturas pertencente à família Cucurbitaceae (Lisboa, 1962).

A sensibilidade diferencial a fungicidas também tem sido utilizada para caracterizar a variabilidade entre isolados de um determinado fungo, possibilitando verificar diferenças no crescimento micelial, e relacionar a sensibilidade dos isolados ao local de origem dos mesmos, possibilitando observar evolução adaptativa do fungo para diferentes condições ambientais (Artigiani Filho \& Bedendo, 1996; Badel \& Kelemu, 1997). Outra ferramenta bastante útil na caracterização de isolados de uma espécie fúngica é a eletroforese de isoenzimas. Os padrões isoenzimáticos dos isolados muitas vezes refletem a variabilidade existente no fungo, potencializando essa técnica para estudos da variabilidade genética de espécies de Colletotrichum (Bach \& Kimati, 1995a,b; Furtado et al., 1999; Figueiredo et al., 1993).

Finalmente, nos últimos anos, o advento das técnicas moleculares para análise do DNA tem permitido grandes progressos na caracterização dos fungos. Essas técnicas tem sido utilizadas para diversos fungos, porém, particularmente para o gênero 
Colletotrichum, elas têm auxiliado grandemente na demonstração da variabilidade inter e intraespecífica. As técnicas mais empregadas com essa finalidade são o "Restriction Fragment Length Polymorphism” (RFLP) e "Random Amplified Polymorphic DNA" (RAPD). Através de testes de inoculação cruzada e marcadores moleculares, Hayden et al. (1994) conseguiram separar o biótipo de infectivo a manga dos demais isolados do complexo C. gloeosporioides. Mills et al. (1992), conseguiram separar isolados de $C$. gloeosporioides oriundos de manga de demais isolados de C. gloeosporioides apenas utilizando marcadores moleculares. Braithwaite et al. (1990), utilizaram a técnica de RFLP para demonstrar a divergência genética entre C. gloeosporioides tipos A e B, duas populações com diferenças morfológicas, patogênicas e bioquímicas que ocorrem em Stylosanthes, na Austrália. Utilizando essa técnica, esses autores revelaram que ambas as populações são geneticamente homogêneas, porém distintas entre si. O fato de não ocorrerem as fases perfeitas de nenhuma dessas populações na Austrália, explica a uniformidade genética intrapopulacional e descarta a possibilidade de especialização patogênica dessa espécie. Dessa forma, os autores concluem que a existência de duas populações tão diferentes só pode ser explicada por duas diferentes introduções do patógeno no país.

A técnica de RAPD foi utilizada no Brasil, numa série de trabalhos, para caracterizar isolados de C. lindemuthianum do feijoeiro (Vilarinhos et al., 1995; AlzateMarin et al., 1997; Mesquita et al., 1998). Nesses trabalhos, foram utilizados diversos isolados do fungo, numa tentativa de discriminar as diferentes raças por meio da técnica de RAPD. Apesar dos resultados não terem permitido o mesmo agrupamento obtido com os testes de inoculação em variedades diferenciadoras, a técnica mostrou bom potencial na caracterização da variabilidade patogênica de $C$. lindemuthianum. Além dessa espécie, o RAPD já foi utilizado, com sucesso, para caracterizar a variabilidade de $C$. graminicola (Guthrie et al., 1992; Browning et al., 1999), C. orbiculare (Correll et al., 1993) e C. gloeosporioides (Alahakoon et al., 1994; Hayden et al., 1994; Kelemu et al., 1999). 


\section{CARACTERIZAÇÃO CULTURAL E MORFOLÓGICA DE ISOLADOS DE}

\section{Colletotrichum lagenarium}

\section{Resumo}

A antracnose, doença causada por fungos do gênero Colletotrichum, é uma das doenças mais importantes em muitas plantas cultivadas. Nas cucurbitáceas, como pepino, chuchu, melão, melancia e abóbora, a antracnose é muito freqüente e causa prejuízos bastante elevados. O agente causal é o Colletotrichum lagenarium, que apresenta como sinonímias C. orbiculare e C. gloeosporioides f. sp. cucurbitae. O presente trabalho visa caracterizar cultural e morfologicamente os isolados de $C$. lagenarium, isolados de plantas da família Cucurbitaceae. Os isolados foram obtidos através de isolamento de tecidos de plantas que apresentavam sintomas de antracnose, e alguns isolados foram adquiridos através da colaboração de outros pesquisadores. A caracterização cultural envolveu a avaliação do crescimento micelial, esporulação, coloração da colônia, topografia da colônia, formação de setores, presença e coloração de massa conidial. Para tanto, os isolados foram cultivados nos meios de cultura BDA, meio de Aveia e meio V8. O crescimento micelial foi avaliado através da mensuração diária do crescimento da colônia, e transformação dos dados em índice de crescimento micelial diário. A esporulação foi avaliada através da contagem dos conídios em suspensão, e posteriormente os dados foram transformados em número de conídios $/ \mathrm{cm}^{2}$ de colônia. As avaliações de coloração e topografia da colônia, formação de setores, presença e coloração de massa conidial foram realizadas através de análise 
visual das colônias. A caracterização morfológica dos isolados compreendeu a avaliação das formas e dimensões dos conídios e apressórios dos isolados, cultivados em meio de Aveia. A caracterização dos conídios foi feita mediante visualização dos mesmos em suspensão com auxílio de microscópio óptico. Para caracterizar os apressórios, os conídios em suspensão foram incubados sobre placas de polietileno, e após germinação foram visualizados em microscópio óptico. Para a maioria dos isolados o meio de Aveia apresentou os melhores resultados para o crescimento micelial e esporulação, contudo todos isolados apresentaram crescimento micelial e esporulação em todos meios de cultura testados. Quanto à caracterização cultural, os isolados apresentaram uma variabilidade muito grande quanto a cor e topografia da colônia e formação de setores, contudo quando analisada a coloração da massa micelial, nos isolados em que esta se fez presente, a coloração não apresentou grandes variações. Apesar da grande variação encontrada nos índices de crescimento micelial diário entre os isolados, não existiu grande variação para cada isolado quando se alterou o meio de cultivo. A esporulação não apresentou correlação com o crescimento micelial, e não se apresentou como bom parâmetro para caracterização, pela variação que apresenta tanto entre os isolados, quanto entre os meios de cultivo. Os conídios dos isolados apresentaram os formatos cilíndrico, clavado e ligeiramente curvo, com dimensões médias variando de 2,25 a

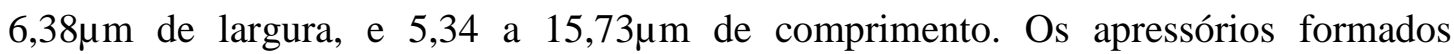
apresentaram os formatos globoso, clavado e lobado ou irregular, com dimensões médias variando de 5,54 a 8,68 $\mu$ m de largura, e 6,71 a 10,75 $\mu$ m de comprimento.

\section{Cultural and morphological characterization of Colletotrichum lagenarium isolates}

\section{Summary}

Anthracnose is one of the most important diseases of cucurbitaceous plants, causing severe damage to cucumber, chayote, melon, watermelon and pumpkin. The 
causal agent is Colletotrichum lagenarium (syn. C. orbiculare, C. gloesporioides f. sp. cucurbitae). The objective of this work was to determine cultural and morphological characterization of $C$. lagenarium, isolated from plants of the Cucurbitaceae family. The isolates used in this study were obtained through isolation from plants presenting symptoms of anthracnose. Isolates were cultivated in potato-dextrose-agar (PDA), Oat and V8 media. The cultural characterization involved the evaluation of mycelial growth, sporulation, colony color, colony topography, sectors formation, presence and color of conidial mass. The mycelial growth was evaluated through the daily measurement of the growth of the colony, and transformation of the data in index of daily mycelial growth. The sporulation was evaluated through the counting of the conidia suspension, and the later data were transformed into number of conidia/cm2 of colony. The shape and size of the conidia and apressoria were assessed to the morphological characterization. For most isolates, the Oat medium showed the best results for mycelial growth and sporulation. However, all isolates showed mycelial growth and sporulation in all the media tested. Colonies of all isolates presented great variability in color, topography, and sectors formation; however, the color of the mycelial mass did not present great variations. Despite the great variation found in the daily mycelial growth indices among the isolates, great variation for each one did not exist when the culture medium was changed. The sporulation did not present correlation with mycelial growth, showing a high variation among the isolates and the culture media. This later parameter was not useful for characterization. The conidia of the isolates were classified in the shapes cylindrical, clavate and slightly curved, with average dimensions varying from 2.25 to $6.38 \mu \mathrm{m}$ in width, and from 5.34 to $15.73 \mu \mathrm{m}$ in legth. The apressoria had the shapes globose, clavate and lobed or irregular, with average dimensions varying from 5.54 to $8.68 \mu \mathrm{m}$ in width, and 6.71 to $10.75 \mu \mathrm{m}$ in length. 


\subsection{Introdução}

A antracnose, doença causada por fungos do gênero Colletotrichum, é uma das doenças mais importantes em muitas plantas cultivadas. Nas cucurbitáceas, como pepino, chuchu, melão e melancia, a antracnose é muito freqüente e causa prejuízos bastante elevados. Ocorre com maior severidade em clima ameno a quente, em épocas chuvosas. Nessas condições, quando não se faz um controle adequado, a doença pode provocar prejuízos de 100\% em pouco tempo (Agrios, 1997; Kurozawa \& Pavan, 1997; Thompson \& Jenkins, 1985; Sitterly \& Keinath, 1996).

Patógenos do gênero Colletotrichum têm sido relatados parasitando mais de uma centena de plantas angiospermas (Alexopoulos et al., 1996). Dentro desse gênero existe especialização para determinados grupos de hospedeiros, como por exemplo, $C$. graminicola, que ataca algumas Poáceas e C. lindemuthianum, patógeno do feijoeiro. No caso da antracnose das cucurbitáceas, o agente causal é descrito na literatura como sendo C. lagenarium, que apresenta como sinonímia C. orbiculare e C. gloeosporioides f. sp. cucurbitae (Kurozawa \& Pavan, 1997; Correll et al. 1993; Sitterly \& Keinath, 1996).

Em grande parte dos casos, a distinção entre espécies de Colletotrichum é feita com base em características morfológicas dos esporos e apressórios. Sutton (1992), fornece descrição para cerca de 40 espécies, porém, esse autor afirma que a taxonomia de Colletotrichum é confusa e que, os critérios morfológicos são de pouco interesse quando informações mais detalhadas sobre um determinado isolado fitopatogênico são necessárias. Cannon (2000) e Menezes (2002) compartilham da mesma opinião.

Na literatura é possível encontrar um número muito grande de trabalhos sobre a caracterização inter e intraespecífica de Colletotrichum. Os métodos utilizados para essas caracterizações são os mais variados, porém os mais freqüentes são a patogenicidade, análise isoenzimática e sensibilidade à fungicidas, além das tradicionais análises morfológica e cultural. Esses trabalhos de caracterização trazem informações extremamente importantes para o conhecimento da variabilidade de determinadas espécies numa região, informações essas que são de grande interesse quando se busca o 
controle das doenças causadas por essas espécies, seja por meio de resistência genética, uso de fungicidas ou práticas culturais.

Bernstein et al. (1995), compararam setenta e dois isolados de Colletotrichum isolados de pêssego, maçã, pecan, morango e abacate. Os isolados puderam ser separados por coloração da colônia em dois grupos. O grupo que apresentou coloração rosada a alaranjada foi identificado como sendo C. acutatum e apresentou conídios com formato fusiforme, além de crescer em meio suplementado com benomyl. O outro grupo de isolados apresentou colônias acinzentadas, conídios com extremidades arredondadas e crescimento nulo em meio com benomyl. Este último grupo foi identificado como sendo C. gloeosporioides. Porém, apesar das diferenças descritas acima, testes de patogenicidade, em frutos destacados de pessegueiro, revelaram não ser possível distinguir os sintomas causados pelas duas espécies. Os autores concluiram que ambas as espécies ocorrem indistintamente causando doenças em pêssego, maçã e pecan. No Brasil, em dois estudos semelhantes à esse último (Goes \& Kimati, 1997a;b), encontraram resultados semelhantes. Os autores verificaram que, tanto $C$. gloeosporioides como C. acutatum, ocorrem naturalmente em plantas cítricas com sintomas de queda prematura dos frutos. Da mesma forma, os isolados de $C$. gloesporioides apresentaram coloração cinza, conídios ligeiramente maiores e crescimento rápido em meio de cultura. Os isolados de C. acutatum apresentaram coloração alaranjada, conídios menores e crescimento lento. Também houveram diferenças marcantes na forma dos apressórios entre as duas espécies. Além dessas diferenças culturais e morfológicas, os resultados dos testes de patogenicidade revelaram que somente os isolados de C. acutatum reproduziram os sintomas de queda prematura dos frutos.

Assis et al. (2001), verificaram diferenças na agressividade entre seis isolados de C. gloeosporioides de frutos de mangueira por meio de testes de patogenicidade em frutos destacados, além disso, esses isolados se diferenciaram quanto ao crescimento micelial e esporulação quando diferentes fontes de carbono foram incorporadas ao meio de cultivo. 
O presente trabalho objetivou caracterizar morfológica e culturalmente isolados de C. lagenarium, e identificar qual meio de cultura proporciona melhores condições para crescimento e esporulação dos isolados.

\subsection{Material e Métodos}

\subsubsection{Obtenção dos isolados}

Os isolados de C. lagenarium foram obtidos de plantas da família das cucurbitáceas, dentre elas chuchu (Sechium edule), pepino (Cucumis sativus), melão (Cucumis melo), abóbora (Cucurbita pepo) e melancia (Citrullus lanatus), provenientes de diferentes localidades.

Os materiais vegetais infectados com esses patógenos, encontrados durante visitas às propriedades produtoras ou recebidos na Clínica Fitopatológica da ESALQ, foram submetidos ao processo de isolamento no laboratório. Para isso, fragmentos infectados desses materiais foram desinfestados com álcool 70\% por 30 segundos, e hipoclorito de sódio $0,5 \%$ por 30 segundos, com posterior plaqueamento em meio BDA. Após o isolamento e formação de colônia, todos os isolados foram repicados para tubos de ensaio contendo meio BDA inclinado e, posteriormente à formação de colônia, foram imersos em óleo mineral Nujol® ${ }^{\circledR}$ autoclavado. Alguns isolados foram cedidos por pesquisadores de outras Universidades e Instituições de pesquisa do Brasil.

Todos os ensaios foram realizados com culturas monospóricas obtidas de cada isolado, de forma a assegurar uniformidade genética do patógeno. A cultura monospórica foi obtida através do plaqueamento em agar-água (1\%) da suspensão dos conídios, diluída a ponto de possibilitar a repicagem dos conídios germinados, individualmente. Todas as culturas monospóricas foram armazenadas em tubos de ensaio contendo meio BDA inclinado, e após a formação da colônia, imersos em óleo mineral Nujol® autoclavado. 


\subsubsection{Caracterização cultural de isolados de C. Iagenarium}

A caracterização cultural foi realizada cultivando-se os isolados monospóricos de C. lagenarium, em três meios de cultura, e avaliando o crescimento micelial, a formação de setores, a topografia e coloração da colônia, e a esporulação.

\subsubsection{Crescimento micelial em diferentes meios de cultura}

Os meios de cultura utilizados foram: meio BDA, meio de aveia e meio V8, preparados segundo Tuite (1969).

Discos de micélio de cinco milímetros de diâmetro, foram transferidos das bordas das culturas dos isolados, cultivados em meio BDA durante aproximadamente sete dias, para novas placas de Petri descartáveis, de oito centímetros de diâmetro, contendo os meios de cultura BDA, meio de aveia e meio V8. Após a repicagem, as placas foram mantidas em fotoperíodo alternado de 12 horas, à temperatura de $20 \pm 1{ }^{\circ} \mathrm{C}$, para o desenvolvimento dos isolados. A partir do segundo dia após a repicagem, foi feita a mensuração diária do diâmetro das colônias em dois sentidos perpendiculares, com auxílio de paquímetro milimetrado, diariamente. As avaliações encerraram no momento em que um dos isolados atingiu a borda da placa. Com os dados obtidos das mensurações, foi determinado para cada isolado, o índice de crescimento micelial, em centímetros por dia. Foram repicadas 4 placas para cada isolado, em cada meio de cultura, onde cada placa representou uma repetição, em um delineamento bifatorial. Os dados resultantes das avaliações foram analisados pelo programa estatístico SAS (Statistical Analisys Sistem), onde foi aplicado teste de Tukey para as médias, ao nível de 5\% de significância, e teste Cluster para agrupamento, conforme a similaridade apresentada entre os isolados. 


\subsubsection{Formação de setores, topografia e coloração da colônia}

A formação de setores foi avaliada através da análise visual e contagem do número de setores que cada isolado apresentou ao final do ensaio de caracterização cultural, calculando-se o número médio de setores formados por colônia para cada isolado. A topografia das colônias foi avaliada através da visualização do comportamento do crescimento micelial, observando-se crescimento imerso no meio de cultura ou aéreo; densidade do micélio produzido, considerando o crescimento mais vigoroso (denso), menos vigoroso (ralo) ou intermediário; e altura da colônia, considerando baixo o micélio que crescia rente ao meio de cultura, porém não imerso (quando o micélio se apresentou totalmente imerso não se aferiu a altura da colônia), alto o micélio que cresceu até metade da altura da placa de Petri, e mediano para os casos intermediários. A coloração foi avaliada durante o crescimento das colônias, observando-se tanto a coloração do micélio imerso quanto aéreo, a coloração observada no fundo da placa, e a coloração da mucilagem da massa conidial, quando esta estava presente. Os isolados foram cultivados em meio de Aveia durante 7 dias, em fotoperíodo alternado de 12 horas, à temperatura de $20 \pm 1^{\circ} \mathrm{C}$.

\subsubsection{Esporulação em diferentes meios de cultura}

A mensuração da esporulação foi realizada ao final do ensaio de crescimento micelial, utilizando-se as mesmas colônias do ensaio de crescimento micelial. Os conídios foram removidos de cada placa com uso de $6 \mathrm{ml}$ de água destilada, e auxílio de uma alça de Drigalski, sendo filtrados em gaze para eliminação dos restos dos meios de cultura e pedaços de micélio e, contados em hemacitômetro. A partir do resultado da contagem dos esporos em hemacitômetro, calculou-se o número de esporos por $\mathrm{cm}^{2}$ de colônia, utilizando o diâmetro médio da colônia, mensurado no último dia de avaliação de crescimento das colônias. Foram realizadas duas contagens para cada placa, totalizando 8 contagens para cada isolado, onde cada contagem representou uma repetição. Os dados resultantes das avaliações foram analisados pelo programa 
estatístico SAS (Statistical Analisys Sistem), onde foi aplicado teste de Tukey para as médias, ao nível de 5\% de significância, teste Cluster para agrupamento, conforme a similaridade das médias.

\subsubsection{Caracterização morfológica de isolados de C. Iagenarium}

\subsubsection{Caracterização dos conídios}

Os isolados monospóricos de C. lagenarium foram repicados para placas de Petri descartáveis, de oito centímetros de diâmetro, contendo meio de Aveia. Após a repicagem, as placas foram mantidas em fotoperíodo de 12 horas, à temperatura de $20 \pm$ $1 \stackrel{\circ}{\mathrm{C}}$, para o desenvolvimento dos isolados. Decorrido período de sete dias para desenvolvimento e esporulação dos isolados, os conídios foram removidos de cada placa com uso de seis mililitros de água destilada e auxílio de uma alça de Drigalski, sendo posteriormente filtrados em gaze para eliminação dos restos dos meios de cultura e pedaços de micélio.

\subsection{Caracterização quanto à forma dos conídios}

Com a suspensão de conídios, foram confeccionadas lâminas para observação dos isolados quanto à forma do conídio em microscópio óptico, com aumento de 400 vezes. Os formatos de conídios observados foram comparados com os formatos de conídios de Colletotrichum spp. descritos por Sutton (1980, 1992). Foram observadas quatro lâminas por isolado, sendo caracterizados 50 conídios em cada lâmina. Os resultados foram transformados em porcentagens de cada formato apresentado pelo isolado.

\subsection{Caracterização quanto às dimensões dos conídios}

Efetuou-se a medição do comprimento e largura de 50 conídios por lâmina, sendo quatro lâminas por isolado. Para tal, utilizou-se de equipamento composto por 
monitor de vídeo Panasonic (Color Vídeo Monitor CT-2084Y), câmara de vídeo (Digital Color Câmera CCD 1/3” SDC-320 Sansung) aclopada a microscópio óptico (Olympus CH2) e lâmina graduada (Carl Zeiss).

O método consistiu em projetar a imagem dos conídios na tela de um monitor de vídeo, e medir diretamente na tela, o comprimento e a largura dos conídios com auxílio de um paquímetro.

Para calibração do equipamento, inicialmente obteve-se um fator de conversão da unidade cm (medida na tela) para $\mu \mathrm{m}$ (dimensão real dos conídios). Projetando-se a lâmina graduada (Carl Zeiss) no monitor, através do aumento de 40x (lente EA40; 0,65; 160/0.17) do microscópio óptico, 5 subdivisões de 0,01mm da régua gravada no corpo da lâmina foram medidas no monitor com auxílio de um paquímetro, o que resultou em uma distância de $22,5 \mathrm{~cm}$. Por regra de três simples obteve-se que $1 \mathrm{~cm}$ medidos na régua correspondeu a 2,22 $\mu \mathrm{m}$. Assim, a medida de largura ou comprimento dos conídios obtidas em centímetros, multiplicadas por 2,22, resultou na dimensão dos mesmos em $\mu \mathrm{m}$.

\subsubsection{Caracterização dos apressórios}

Para a caracterização dos apressórios, as suspensões dos conídios foram colocadas para germinar sobre placas de polietileno. Foram colocadas quatro gotas de $20 \mu \mathrm{l}$ em cada placa, para cada isolado, totalizando quatro repetições. As placas foram mantidas em bandejas de polietileno com dimensões de $37 \mathrm{~cm}$ de comprimento, $26 \mathrm{~cm}$ de largura e $12 \mathrm{~cm}$ de altura, sendo colocadas toalhas de papel umedecidas com água destilada ao fundo, e posteriormente cobertas com plástico a fim de estabelecer uma câmara úmida. Este procedimento foi adotado com a finalidade de evitar a evaporação da água da suspensão antes da germinação dos conídios e formação dos apressórios. 


\subsection{Caracterização quanto à forma dos apressórios}

A forma do apressório foi definida através da visualização do mesmo em microscópio óptico, com aumento de 400 vezes. Para tanto, foi colocada uma lamínula sobre a gota de suspensão com apressórios formados para facilitar a focalização. Foi utilizado aumento de 400 vezes. Foram observadas quatro gotas por isolado, sendo caracterizados 25 apressórios em cada gota. Os resultados foram transformados em porcentagens de cada formato apresentado pelo isolado. Os formatos foram identificados conforme descrição de formatos de apressórios de Colletotrichum spp. oferecida por Sutton $(1980,1992)$.

\subsection{Caracterização quanto às dimensões dos apressórios}

Para realizar as mensurações de comprimento e largura dos apressórios considerou-se, como comprimento, a distância entre o septo (existente entre o apressório e o tubo germinativo) e a extremidade do apressório mais distante do mesmo. A largura foi mensurada em sentido perpendicular ao considerado para o comprimento. A avaliação seguiu a mesma metodologia da caracterização dos conídios, utilizando-se equipamento composto por monitor de vídeo Panasonic (Color Vídeo Monitor CT2084Y), câmara de vídeo (Digital Color Câmera CCD 1/3” SDC-320 Sansung) aclopada a microscópio óptico (Olympus CH2) e lâmina graduada (Carl Zeiss), projetando-se a imagem dos apressórios na tela do monitor de vídeo, e medindo diretamente na tela do mesmo o comprimento e largura dos apressórios com auxílio de um paquímetro.

A mesma calibração do equipamento utilizada para medir as dimensões dos conídios foi utilizada para medir as dimensões dos apressórios. Foram observadas quatro gotas por isolado, sendo mensurados 25 apressórios em cada gota. Os dados resultantes foram transformados em médias de diâmetro e comprimento dos apressórios para cada isolado. 


\subsection{Resultados e Discussão}

\subsubsection{Coleção de isolados de C. lagenarium}

Através de isolamento no Laboratório de Micologia e Clinica Fitopatológica, e da contribuição de demais pesquisadores, foi constituída uma coleção com 25 isolados de C. lagenarium, oriundos de cucurbitáceas com sintomas de antracnose. Na Tabela 1 encontram-se relacionados os isolados com sua identificação, hospedeiro do qual foi isolado, local de origem e data do isolamento.

Tabela 1. Relação de isolados de Colletotrichum lagenarium

\begin{tabular}{cllc}
\hline Isolado & Hospedeiro & Procedência & Isolamento \\
\hline CH-1 & Chuchu & Londrina-PR & 1999 \\
CH-3 & Chuchu & Londrina-PR & 2001 \\
CH-4 & Chuchu & Londrina-PR & 2001 \\
PE-1 & Pepino & Piracicaba-SP & 2001 \\
PE-3 & Pepino & Recife-PE & mar/00 \\
PE-4 & Pepino & Recife-PE & mar/00 \\
PE-5 & Pepino & Recife-PE & mar/00 \\
PE-6 & Pepino & Recife-PE & mar/00 \\
CL-5 & Pepino Adoai & Vitória de Santo Antão-PE & mai/00 \\
CL-7 & Pepino Híbrido Jóia AG454 & Sairé-PE & mai/00 \\
CL-11 & Pepino Aldacha & Sairé-PE & mai/00 \\
CL-15 & Pepino Caipira & Gravatá-PE & mai/00 \\
CL-20 & Pepino Caipira & Chão Grande-PE & jul/00 \\
CL-22 & Pepino Caipira & Vitória de Santo Antão-PE & jul/00 \\
CL-41 & Pepino Híbrido Eureka & Camocim de São Felix-PE & jul/00 \\
AB-274 & Abóbora & Campinas-SP & jul/00 \\
AB-1 & Abobrinha de moita & Piracicaba-SP & out/03 \\
AB-2 & Abóbora & Piracicaba-SP & nov/03 \\
AB-3 & Abóbora & Assis-SP & nov/03 \\
MA-1 & Melancia & Oscar Bressane-SP & nov/03 \\
MA-2 & Melancia & Marília-SP & jan/04 \\
MA-3 & Melancia & São Carlos-SP & jan/04 \\
ME-1 & Melão & Pará & mar/03 \\
ME-2 & Melão Sharantine & Bragança Paulista-SP & jan/04 \\
ME-3 & Melão Sharantine & Bragança Paulista-SP & jan/04 \\
\hline & & &
\end{tabular}




\subsubsection{Caracterização cultural de isolados de C. Iagenarium}

\subsubsection{Crescimento micelial em diferentes meios de cultura}

Os meios de cultura, de maneira geral, induziram um bom crescimento micelial para a maioria dos isolados. Nota-se que tanto entre os meios de cultura, quanto entre os isolados houve diferença estatística significativa entre os resultados (Tabela 2). Entre os meios de cultura, o meio de Aveia apresentou os melhores resultados para crescimento micelial diário para a maioria dos isolados, com médias variando de 0,57 a 1,57 cm/dia. Os resultados obtidos com o crescimento micelial em meio de Aveia não diferiram dos resultados obtidos no meio BDA para os isolados CH01, CH03, CL11, AB01, MA01, MA02, e ME03, e também não diferiram dos resultados obtidos no meio V8 para os isolados CH01, CH03, MA01 e MA02. Estes resultados concordam em parte com os resultados obtidos por Assis et al. (2001) que, testando fontes de carbono na nutrição de Colletotrichum gloeosporioides, concluíram que o amido proporcionou melhor crescimento micelial para a maioria dos isolados, provavelmente devido o amido ser um composto que se hidrolisa lentamente, proporcionando menor acúmulo de ácidos no meio, não prejudicando o desenvolvimento do fungo. O meio BDA apresar de apresentar amido em sua composição, também apresenta dextrose e demais elementos contidos no caldo de batata, elementos que podem estar corroborando com as diferenças dos resultados entre os meios BDA e meio de Aveia. Entre os meios BDA e V8, houve diferenças no crescimento micelial apenas para o isolado ME03. As médias dos resultados de crescimento micelial diário em meio BDA variaram de 0,46 a 1,26 cm/dia, e em meio V8 variaram de 0,47 a $1,13 \mathrm{~cm} /$ dia.

Sutton (1992) refere-se à velocidade de crescimento de C. lagenarium como tão lenta quanto a de C. gloeosporioides ou C. acutatum. Vinnere (2004), concluiu que, o crescimento mais lento de C. acutatum perante C. gloeosporioides parece ser a única característica cultural realmente estável, e que pode promover resultados reproduzíveis, auxiliando a separação das duas espécies, ainda Kuramae-Izioka et al. (1997) observaram que isolados monospóricos de C. gloeosporioides apresentam mesmo índice de crescimento micelial que seus isolados de origem. Trabalhando com caracterização 
de isolados de Colletotrichum, Bernstein et al. (1995) separaram os isolados da espécie C. gloeosporioides de isolados da espécie C. acutatum através do crescimento micelial em meio de cultura BDA e BDA+Benomyl. Neste trabalho os isolados de $C$. gloeosporioides apresentaram crescimento relativamente mais rápido em meio BDA, porém não apresentando crescimento em meio adicionado de benomyl, enquanto que isolados de $C$. acutatum apresentaram crescimento mais lento em BDA, e não foram inibidos pela adição de benomyl ao meio de cultura.

Tabela 2 Médias de crescimento micelial diário de isolados de Colletotrichum lagenarium nos meios de Aveia, meio BDA e meio V8

\begin{tabular}{|c|c|c|c|c|c|c|c|c|c|c|}
\hline \multirow{3}{*}{$\frac{\text { Isolados }}{\text { ME02 }^{1}}$} & \multirow{3}{*}{$\begin{array}{c}\text { Grupo } \\
1\end{array}$} & \multicolumn{9}{|c|}{ Médias do Crescimento Micelial Diário (cm/dia) } \\
\hline & & \multicolumn{3}{|c|}{ AVEIA } & \multicolumn{3}{|c|}{ BDA } & \multicolumn{3}{|c|}{ V8 } \\
\hline & & 1,57 & A & a & 1,26 & B & $\mathrm{ab}$ & 1,13 & $\mathrm{~B}$ & a \\
\hline MA03 & 1 & 1,44 & A & $\mathrm{ab}$ & 1,20 & $\mathrm{~B}$ & abc & 1,04 & $\mathrm{~B}$ & abcd \\
\hline ME03 & 1 & 1,43 & A & abc & 1,36 & A & $\mathrm{a}$ & 1,05 & $\mathrm{~B}$ & $\mathrm{ab}$ \\
\hline ME01 & 2 & 1,31 & A & bcd & 1,09 & B & bcde & 0,91 & B & bcde \\
\hline CL22 & 2 & 1,27 & A & bcd & 0,95 & B & efg & 0,86 & B & cdef \\
\hline CL07 & 2 & 1,26 & A & bcd & 1,02 & B & cdef & 0,84 & B & def \\
\hline CL11 & 2 & 1,25 & A & $\mathrm{cd}$ & 1,18 & $\mathrm{AB}$ & abcd & 1,00 & B & abcd \\
\hline CL41 & 2 & 1,25 & A & cd & 1,01 & B & def & 0,87 & B & bcdef \\
\hline CL15 & 3 & 1,21 & A & de & 0,94 & B & efgh & 0,80 & B & efgh \\
\hline CL20 & 3 & 1,20 & A & de & 0,82 & B & ghijk & 0,77 & B & efghi \\
\hline PE05 & 3 & 1,16 & A & de & 0,94 & B & efg & 0,82 & B & def \\
\hline PE04 & 3 & 1,16 & A & ijk & 0,91 & B & efgh & 0,76 & B & efghij \\
\hline PE06 & 3 & 1,15 & A & def & 0,90 & B & fghi & 0,82 & B & defg \\
\hline AB03 & 3 & 1,14 & A & defg & 0,78 & B & ghijkl & 0,72 & B & fghijkl \\
\hline AB02 & 3 & 1,14 & A & defg & 0,85 & B & fghij & 0,78 & B & efghi \\
\hline PE03 & 3 & 1,06 & A & efgh & 0,87 & B & fghij & 0,73 & B & efghijk \\
\hline CL05 & 4 & 0,97 & A & fghi & 0,71 & B & ijklm & 0,54 & B & $\operatorname{lm}$ \\
\hline AB274 & 4 & 0,96 & A & ghi & 0,59 & B & $\operatorname{lmn}$ & 0,62 & B & hijklm \\
\hline AB01 & 4 & 0,90 & A & hij & 0,75 & $\mathrm{AB}$ & hijklm & 0,63 & B & hijklm \\
\hline PE01 & 4 & 0,86 & A & ijk & 0,68 & B & jklm & 0,57 & B & $\mathrm{klm}$ \\
\hline MA02 & 5 & 0,73 & A & jkl & 0,65 & A & klmn & 0,63 & A & ghijklm \\
\hline CH01 & 5 & 0,71 & A & jkl & 0,66 & A & $\mathrm{klm}$ & 0,58 & A & jlkm \\
\hline MA01 & 5 & 0,69 & A & $\mathrm{kl}$ & 0,56 & A & $\mathrm{mn}$ & 0,60 & A & ijklm \\
\hline CH04 & 6 & 0,69 & A & $\mathrm{kl}$ & 0,31 & B & o & 0,46 & B & $\mathrm{m}$ \\
\hline CH03 & 6 & 0,57 & A & l & 0,46 & A & no & 0,47 & A & $\mathrm{m}$ \\
\hline CV (\%) & & \multicolumn{3}{|c|}{9,5} & \multicolumn{3}{|c|}{7,6} & \multicolumn{3}{|c|}{11,2} \\
\hline
\end{tabular}


Com os resultados obtidos, pode-se concluir que os isolados de C. lagenarium, em sua maioria, apresentam velocidade de crescimento micelial dentro da faixa proposta para as espécies de C. gloeosporioides e C. acutatum, de acordo com Sutton (1992). A análise estatística e de agrupamento mostraram que as diferenças nos crescimentos entre os meios de cultura são mantidas para quase todos isolados (Tabela 2), podendo-se assim dizer que existe reprodutibilidade dos resultados para os isolados, conforme já descrito por Vinnere (2004).

\subsubsection{Formação de setores, topografia e coloração da colônia}

Os setores foram identificados pela presença de áreas claras em colônias que normalmente exibiam coloração escura, ou áreas escuras em colônias que normalmente exibiam coloração clara. O número de setores variou de zero a três por colônia, no entanto apenas 8 isolados apresentaram colônias com setores, indicando que a variabilidade apresentada pela coleção de isolados foi pequena. O fato de poucos isolados estarem apresentando setores, e o pequeno número de setores apresentado por estes isolados, provavelmente está relacionado com a utilização de culturas monospóricas nos ensaios, o que reduz a variabilidade de cada isolado, e possibilita uma maior reprodutibilidade de resultados. A baixa variabilidade foi observada através da drástica redução do número de setores apresentada pelos isolados monospóricos quando comparados com seus isolados de origem (dados não apresentados), no entanto notou-se que nem todos isolados se apresentaram da mesma forma. Kuramae-Izioka et al. (1997), assim como Liyanage et al. (1992) também observaram formação de setores em isolados monospóricos de C. gloeosporioides. Artigiani \& Bedendo (1996), relatam que a formação de setores e a variação da quantidade dos setores em isolados de Helminthosporium oryzae, demonstra a variabilidade dos isolados. 
Tabela 3 Topografia, coloração micelial, cor de fundo da placa, formação de setores, presença e coloração da massa conidial de isolados de C. lagenarium, cultivados em meio de Aveia

\begin{tabular}{|c|c|c|c|c|c|}
\hline Isolado & Topografia da colônia & Coloração do micélio & Cor fundo de placa & Setor & Massa conidial \\
\hline$\overline{\mathrm{CH}} 1^{1}$ & aéreo, denso, baixo, cotonoso & cinza no centro e creme nas extremidades & negro & 2 & salmão \\
\hline CH3 & imerso, ralo & branco a salmão & salmão & 0 & salmão \\
\hline $\mathrm{CH} 4$ & imerso, denso & branco a salmão & salmão & 0 & abundante salmão \\
\hline PE1 & imerso, ralo, pouco micélio aéreo & branco a salmão, branco a cinza & cinza & 2 & laranja \\
\hline PE3 & imerso, denso & cinza escuro e salmão, com extremidades pálidas & laranja e castanho & 0 & abundante, laranja \\
\hline PE4 & imerso, ralo & Cinza escuro, cinza, e salmão & castanho & 2 & laranja \\
\hline PE5 & imerso, denso & cinza escuro e salmão, com extremidade pálida & castanho e laranja & 1 & abundante, laranja \\
\hline PE6 & imerso/aéreo, intermediário, baixo & $\begin{array}{c}\text { cinza escuro quando imerso, branco quando aéreo, acérvulos } \\
\text { distanciados }\end{array}$ & castanho escuro & 0 & laranja a salmão \\
\hline CL05 & cotonoso e alto, aéreo, denso & cinza escuro com extremidade pálida & castanho escuro & 0 & ausente \\
\hline CL07 & imerso/aéreo, denso, baixo, floculoso & creme a branco & creme & 0 & ausente \\
\hline CL11 & aéreo, cotonoso, denso, baixo & negro com extremidades pálida ou creme & negro & 0 & ausente \\
\hline CL15 & imerso/aéreo, intermediário, baixo & $\begin{array}{l}\text { salmão quando imerso, branco quando aéreo, acérvulos castanho } \\
\text { escuros }\end{array}$ & $\begin{array}{l}\text { castanho escuro e } \\
\text { salmão }\end{array}$ & 0 & laranja a salmão \\
\hline CL20 & imerso/aéreo, cotonoso, denso, baixo & creme a branco & creme e salmão & 0 & ausente \\
\hline CL22 & imerso, denso, floculoso, baixo & cinza claro a branco, e salmão & creme e salmão & 1 & ausente \\
\hline CL41 & imerso, denso, floculoso, baixo & creme com extremidade pálida & creme & 0 & ausente \\
\hline AB274 & imerso/aéreo, denso baixo & cinza com extremidade pálida & negro & 0 & ausente \\
\hline AB1 & $\begin{array}{c}\text { denso quando imerso, ralo quando } \\
\text { aéreo, baixo }\end{array}$ & negro no centro e cinza nas extremidades & negro & 0 & ausente \\
\hline AB2 & imerso/aéreo,denso, mediano & salmão no centro e creme nas extremidades & castanho & 0 & laranja \\
\hline AB3 & imerso/aéreo, ralo, mediano & cinza a castanho escuro, com extremidade pálida & negro & 0 & abundante laranja \\
\hline MA1 & imerso e denso & salmão, com centro cinza escuro e extremidade creme & cinza claro & 1 & laranja \\
\hline MA2 & imerso e denso & cinza escuro com extremidades creme & cinza escuro & 3 & ausente \\
\hline MA3 & aéreo, cotonoso, denso, alto & cinza claro com extremidade pálida & branco & 1 & ausente \\
\hline ME1 & aéreo, cotonoso, denso, alto & branco, com centro cinza & branco e salmão & 0 & ausente \\
\hline ME2 & aéreo, cotonoso, denso, alto & branco a cinza com centro cinza esverdeado & $\begin{array}{l}\text { centro escuro e borda } \\
\text { branca }\end{array}$ & 0 & ausente \\
\hline ME3 & aéreo, cotonoso, denso, alto & cinza claro com extremidade pálida & cinza escuro & 0 & ausente \\
\hline
\end{tabular}

1 - $\mathrm{CH}=$ =isolado de chuchu; $\mathrm{PE}=$ =isolado de pepino; $\mathrm{CL}=$ =isolado de pepino; $\mathrm{AB}=$ =isolado de abóbora; $\mathrm{MA}=$ =isolado de melancia; $\mathrm{ME}=$ isolado de melão. 
A coloração apresentada pelas colônias dos isolados variou de branco a tons de cinza, creme, negro, salmão e branco esverdeado. A topografia apresentou desde micélio aéreo, alto e denso à totalmente imerso e ralo. A massa conidial produzida durante a esporulação do fungo não esteve presente em todos os isolados, no entanto, nas colônias que apresentaram massa conidial, esta se apresentou variando nas cores laranja a salmão (Tabela 3). Não foi observada formação de escleródios em nenhuma das colônias.

Conforme a descrição de Sutton $(1980,1992)$ as culturas de C. lagenarium apresentam colônias irregulares, com micélio aéreo abundante branco acinzentado, marrom escuro a negro ou cinza escuro, com margens pálidas e rosadas ou creme. $\mathrm{O}$ reverso da colônia, ou fundo da placa se apresenta marrom escuro. A massa conidial varia de cor-de-rosa a salmão, podendo ou não apresentar escleródios e setas.

Dentro desta coleção de C. lagenarium, os isolados CH1, PE6, CL5, CL11, CL15, AB274, AB1, AB3, MA3, ME1, ME2 e ME3 apresentam características mais próximas às descrições de Sutton $(1980,1992)$, quanto à coloração, topografia e cor de fundo de placa. Os isolados PE1, PE3, PE4, PE5, CL22, MA1 e MA2 diferiram da descrição de Sutton apenas quanto à topografia da colônia, apresentando micélio imerso em meio de cultura, e os isolados CL7, CL20, CL41 e AB2 diferiram na coloração, esta variando de creme a branco, creme, e salmão. Apenas os isolados CH3 e CH4 apresentaram as características mais divergentes da descrição de Sutton, com micélio imerso em meio de cultura, colônias de coloração entre branco e salmão, com fundo de placa salmão.

Contudo, as características de cor e topografia de colônia de C. lagenarium são passíveis de serem confusão com as características da espécie C. gloeosporioides, que apresenta em sua descrição micélio aéreo, de coloração branca acinzentado a cinza escuro, fundo de placa branco a cinza ou escuro, massa conidial de coloração salmão pálido, com escleródios ausentes e setas podendo estar presentes ou ausentes (Sutton, 1980, 1992). Apresar de Ferraz (1977), ter classificado isolados do gênero Colletotrichum em grupos e subgrupos, em função da variação observada nas características culturais, admitindo que a variabilidade encontrada dentro de uma mesma espécie no mesmo substrato seria devido a presença de raças fisiológicas, a grande 
variabilidade encontrada dentro dos 25 isolados de $C$. lagenarium, impede uma imediata identificação dos mesmos como C. lagenarium, apenas pela análise visual da colônia. Artigiani \& Bedendo (1996) não conseguiram agrupar os isolados de Helminthosporium oryzae a partir da ocorrência de setores, sensibilidade a fungicidas, crescimento em diferentes meios de cultura e temperatura de incubação, devido a grande variabilidade apresentada pelos mesmos, tanto entre as diferentes regiões de origem, quanto dentro destas regiões.

Couto \& Menezes (2004), quando analisaram as características culturais de isolados de C. musae, concluíram que a variabilidade encontrada em alguns isolados, pode ser relacionada com a segregação da condição heterozigótica, explicando a diversidade de formas, cores e número de setores que uma população de biótipos pode apresentar. O aspecto cultural dos isolados de C. gloeosporioides de Assis et al. (2004) variou bastante em relação à densidade, cor de micélio e produção de pigmentos nos diferentes meios de cultura. Esta variabilidade apresentada pelas colônias do patógeno, pode ser atribuída ao genótipo de cada isolado, cuja expressão fenotípica está associada ao ambiente de cultivo, assim como a biosíntese de metabólitos secundários, que tem sido caracterizada em Colletotrichum, permitindo o surgimento de variações tanto culturais quanto patogênicas (Bailey \& Jerger, 1992). Outra hipótese levantada por Couto \& Menezes (2004) cuja segregação estaria relacionada à condição heterozigótica poderia também estar relacionada com a variabilidade cultural apresentada pelos isolados de C. lagenarium.

Na medida em que os isolados apresentaram esporulação intensa em meio de cultura, formando massas de conídios evidentes, reforçou-se a hipótese de que os isolados fazem parte da espécie C. lagenarium, pela coloração da massa conidial, contudo não são todos os isolados que apresentam esporulação intensa e formação de massa conidial. Dentre os isolados estudados, todos que apresentaram esporulação evidente em meio de cultura, apresentaram coloração da massa conidial variando em tons de laranja, laranja a salmão, e salmão, como a descrição de Sutton (1980, 1992). Nenhum isolado apresentou coloração salmão pálido ou outro tom empalidecido nas 
massas conidiais, diferenciando-se assim da descrição para esporulação de $C$. gloeosporioides.

\subsubsection{Esporulação em diferentes meios de cultura}

Todos os isolados apresentaram esporulação nos três meios de cultura utilizados, mesmo não se notando a presença de massa conidial em todos isolados. Este fato que mostra que houve formação de esporos a partir de hifas conidiógenas dispersas na colônia. Nota-se que houve interação entre os tratamentos, contudo os meios de cultura não apresentaram diferenças entre si quando analisados todos isolados conjuntamente, no entanto considerando-se cada isolado individualmente, foi possível observar diferenças entre os meios utilizados (Tabela 4). O número de esporos produzidos por centímetro quadrado de colônia variou de $2,22 \times 10^{2}$ a $1,39 \times 10^{8}$, evidenciando uma grande variação para esta característica.

O isolados CH3 e CH4 apresentaram maior esporulação em meio V8, diferindo dos demais meios de cultura, contudo não diferindo dentre os meios BDA e meio de Aveia. Destaca-se o isolado CH4 pela maior produção de conídios em meio V8, superando a produção do isolado $\mathrm{CH} 3$ em $6,92 \times 10^{7}$ conídio $/ \mathrm{cm}^{2}$, em meio V8, e

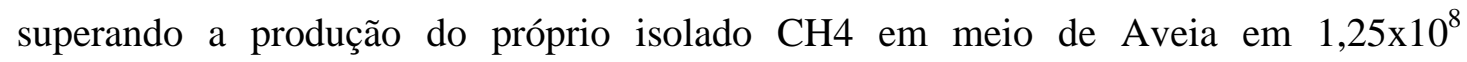
conídios/cm². Os isolados PE6 e AB2 apresentaram maior esporulação em meio de aveia, diferindo dos demais meios de cultura, porém não diferindo entre os meios BDA e V8. Para os demais isolados, a esporulação nos três meios de cultura não apresentou diferenças significativas, quando analisados os meios, exceto para o isolado AB3, onde a esporulação em meio de aveia diferiu da esporulação em meio V8. O teste Cluster dos isolados resultou na formação de quatro grupos, tendo apenas o isolado $\mathrm{CH} 4$ no grupo 1, e o isolado CH3 no grupo 3. Os isolados PE6, AB3 e AB2 foram agrupados no grupo 2, e os demais isolados no grupo 4 (Tabela 4).

Assis et al. (2001) observaram que a esporulação de C. gloeosporioides é favorecida por substratos que contém amido, enquanto que substratos que contém glucose ou maltose como fonte de carbono não foram favoráveis à esporulação. 
Destacam também a possibilidade do isolado que apresentou maior esporulação (2,05 $\times 10^{7}$ conídios/ml) possuir um sistema enzimático mais específico e eficiente na degradação de certos açúcares, tal fato poderia ser relacionado ao comportamento dos isolados PE6 e AB2 como os únicos que apresentaram maior esporulação em meio BDA. Um efeito favorável do amido sobre a esporulação de fungos patogênicos já foi observado por Timnick et al. (1951) que verificaram uma maior reprodução de Diaporthe phaseolorum (Cke. \& Ell.).

Tabela 4. Médias da esporulação de isolados de C. lagenarium nos meios de Aveia, meio BDA e meio V8

\begin{tabular}{|c|c|c|c|c|c|c|c|c|c|c|}
\hline \multirow{3}{*}{$\frac{\text { Isolados }}{\mathrm{CH}^{1} 4^{1}}$} & \multirow{3}{*}{$\begin{array}{c}\text { Grupo } \\
1\end{array}$} & \multicolumn{9}{|c|}{ Média do número de esporos $/ \mathrm{cm}^{2}$} \\
\hline & & \multicolumn{3}{|c|}{ AVEIA } & \multicolumn{3}{|c|}{ BDA } & \multicolumn{3}{|c|}{ V8 } \\
\hline & & 13.881 .140 & $\mathrm{~B}^{2}$ & $\mathrm{a}$ & 11.993 .367 & $\mathrm{~B}$ & $\mathrm{a}$ & 138.789 .622 & A & $\mathrm{a}$ \\
\hline PE06 & 2 & 10.853 .543 & A & $\mathrm{ab}$ & 3.706 .447 & B & abcde & 872.105 & $\mathrm{~B}$ & $\mathrm{~cd}$ \\
\hline AB03 & 2 & 6.999 .080 & A & abc & 4.574 .877 & $\mathrm{AB}$ & abcd & 829.521 & $\mathrm{~B}$ & $\mathrm{~cd}$ \\
\hline AB02 & 2 & 6.227 .709 & A & abcd & 314.172 & $\mathrm{~B}$ & efg & 22.021 & B & $\mathrm{d}$ \\
\hline CH03 & 3 & 6.187 .816 & $\mathrm{~B}$ & bcde & 5.433 .895 & $\mathrm{~B}$ & $\mathrm{ab}$ & 69.585 .031 & A & $\mathrm{b}$ \\
\hline PE05 & 4 & 3.621 .038 & A & cdef & 3.250 .888 & A & bcdefg & 1.228 .737 & A & $\mathrm{cd}$ \\
\hline PE03 & 4 & 2.409 .407 & A & cdef & 5.091 .070 & A & abc & 2.030 .650 & A & $\mathrm{cd}$ \\
\hline MA02 & 4 & 1.477 .845 & A & cdef & 3.689.242 & A & abcdef & 4.973 .749 & A & C \\
\hline CL22 & 4 & 1.209 .198 & A & def & 77.290 & A & fg & 329.808 & A & $\mathrm{d}$ \\
\hline PE04 & 4 & 824.190 & A & def & 316.872 & A & defg & 105.687 & A & $\mathrm{d}$ \\
\hline CL05 & 4 & 744.037 & A & def & 485.661 & A & cdefg & 260.823 & A & $\mathrm{d}$ \\
\hline ME01 & 4 & 671.751 & $\mathrm{~A}$ & def & 8.921 & $\mathrm{~A}$ & g & 97.803 & A & $\mathrm{d}$ \\
\hline ME03 & 4 & 646.002 & A & def & 13.561 & A & g & 107.972 & A & $\mathrm{d}$ \\
\hline MA03 & 4 & 544.560 & A & ef & 19.336 & A & g & 260.643 & A & $\mathrm{d}$ \\
\hline MA01 & 4 & 502.458 & $\mathrm{~A}$ & ef & 115.470 & $\mathrm{~A}$ & efg & 439.367 & A & $\mathrm{d}$ \\
\hline AB01 & 4 & 175.881 & A & $\mathrm{f}$ & 364.135 & A & defg & 1.100 & A & $\mathrm{d}$ \\
\hline CH01 & 4 & 39780 & A & $\mathrm{f}$ & 463 & A & g & 454 & A & $\mathrm{d}$ \\
\hline ME02 & 4 & 23.466 & A & $\mathrm{f}$ & 1.720 .325 & A & bcdefg & 8.140 & A & $\mathrm{d}$ \\
\hline PE01 & 4 & 10.390 & A & $\mathrm{f}$ & 6.717 & A & g & 16.815 & A & $\mathrm{d}$ \\
\hline CL11 & 4 & 8.006 & A & $\mathrm{f}$ & 2.081 & A & g & 791 & A & $\mathrm{d}$ \\
\hline CL15 & 4 & 3.572 & A & $\mathrm{f}$ & 13.015 & A & g & 36.663 & A & $\mathrm{d}$ \\
\hline CL07 & 4 & 2.648 & A & $\mathrm{f}$ & 8.676 & A & g & 17.625 & A & $\mathrm{d}$ \\
\hline CL41 & 4 & 1.475 & A & $\mathrm{f}$ & 136.391 & A & g & 1.632 & A & $\mathrm{d}$ \\
\hline AB274 & 4 & 363 & A & $\mathrm{f}$ & 2.009 & A & g & 225 & A & $\mathrm{d}$ \\
\hline CL20 & 4 & 222 & A & $\mathrm{f}$ & 894 & A & g & 475 & A & $\mathrm{d}$ \\
\hline CV(\%) & 36,62 & & & & & & & & & \\
\hline
\end{tabular}


Trabalhando com Colletotrichum, Assis et al. (2001) não encontrou correlação entre as características culturais dos isolados, como crescimento micelial e esporulação. Este fato também foi observado quanto aos isolados de C. lagenarium deste trabalho. Aplicou-se um teste de correlação entre as médias de crescimento micelial e de esporulação, e encontrou-se um coeficiente de correlação 0,064. Segundo Tandon \& Chandra (1962), um bom crescimento micelial está associado a uma boa esporulação. Couto e Menezes (2004) encontraram em seu trabalho com C. musae tanto isolados que apresentavam bom crescimento micelial e esporulação, quanto um isolado que apresentava alta esporulação e baixo crescimento micelial. Cochrane (1958) relata que nem sempre há relação direta entre crescimento e esporulação, e vice versa. Às vezes, um meio ótimo para o crescimento rápido resulta na exaustão dos nutrientes e em maior concentração os metabólitos secundários liberados pelo fungo nesse meio, inibindo a produção de esporos. Ou seja, nem sempre um substrato ótimo para o crescimento micelial exerce o mesmo efeito sobre a esporulação (Griffin, 1994), por outro lado, o crescimento micelial reduzido pode estimular a esporulação naquele substrato (Couto \& Menezes, 2004).

\subsubsection{Caracterização morfológica de isolados de $C$. lagenarium}

\subsubsection{Caracterização dos conídios}

\subsection{Caracterização quanto à forma do conídio}

Os conídios quando observados ao microscópio óptico, apresentaram-se hialinos, unicelulares, retos, sem formação septo após a germinação, com presença de três formas predominantes: cilíndrico, clavado e semicurvo. Os conídios cilíndricos foram encontrados em todos isolados analisados, variando de 100 a 35\% do total de conídios avaliados por isolado. Os conídios clavados foram encontrados em 20 dos 25 isolados analisados variando de 4 a $40 \%$ do total de conídios avaliados. Os conídios semicurvos foram encontrados em apenas 2 dos 20 isolados analisados, no entanto compunham de 30 a 36\% do total de conídios analisados por isolado (Tabela 5). 
As formas de conídios encontradas assemelham-se com as descritas por Sutton (1980, 1992) e Shen et al. (2001). Estes autores observaram conídios cilíndricos, clavados, levemente curvos, com ápice obtuso e afilados na base, no entanto os isolados que apresentam apenas conídios cilíndricos podem confundir a identificação, pois algumas espécies de Colletotrichum como o grupo C. gloeosporioides apresentam conídios cilíndricos, levando então a necessidade de averiguar outra característica, como suas dimensões, para correta identificação.

Tabela 5. Caracterização morfológica dos conídios de C. lagenarium

\begin{tabular}{lccc}
\hline Isolados & cilíndricos & clavados & semi-curvos \\
\hline CH1 & $70,00^{2}$ & 30,00 & 0,00 \\
CH3 & 35,00 & 35,00 & 30,00 \\
CH4 & 70,00 & 30,00 & 0,00 \\
PE1 & 82,00 & 18,00 & 0,00 \\
PE3 & 92,00 & 8,00 & 0,00 \\
PE4 & 100,00 & 0,00 & 0,00 \\
PE5 & 60,00 & 40,00 & 0,00 \\
PE6 & 100,00 & 0,00 & 0,00 \\
CL5 & 90,00 & 10,00 & 0,00 \\
CL7 & 100,00 & 0,00 & 0,00 \\
CL11 & 5,00 & 36,00 \\
CL15 & 68,00 & 10,00 & 0,00 \\
CL20 & 20,00 & 0,00 \\
CL22 & 90,00 & 8,00 & 0,00 \\
CL41 & 80,00 & 2,00 & 0,00 \\
AB274 & 92,00 & 20,00 & 0,00 \\
AB1 & 98,00 & 15,00 & 0,00 \\
AB2 & 80,00 & 7,00 & 0,00 \\
AB3 & 85,00 & 0,00 & 0,00 \\
MA1 & 93,00 & 14,00 & 0,00 \\
MA2 & 100,00 & 18,00 & 0,00 \\
MA3 & 86,00 & 6,00 & 0,00 \\
ME1 & 82,00 & 25,00 & 0,00 \\
ME2 & 94,00 & 4,00 & 0,00 \\
ME3 & 75,00 & 12,00 & 0,00
\end{tabular}

1 - $\mathrm{CH}=$ =isolado de chuchu; $\mathrm{PE}=$ =isolado de pepino; $\mathrm{CL}=$ =isolado de pepino; $\mathrm{AB}=$ =isolado de abóbora; $\mathrm{MA}=$ =isolado de melancia; ME=isolado de melão. 2 - percentuais 


\subsection{Caracterização quanto às dimensões dos conídios}

Com relação às dimensões dos conídios analisados, estas variaram entre 1,55 a 8,33 $\mu \mathrm{m}$ de largura, 2,89 a 19,99 $\mu \mathrm{m}$ de comprimento, e a relação entre o comprimento e o largura variou entre 2,35 e 3,94. Dentre os isolados analisados, os isolados PE1, PE3, PE4, PE5, CL7, CL11, CL15, CL20, CL22, CL41, AB3 e MA1 apresentaram dimensões dentro da faixa de 4,5 a $6 \mu \mathrm{m}$ de largura e 10 a $15 \mu \mathrm{m}$ de comprimento, dimensões estas descritas por Sutton (1992), para caracterização de conídios de C. lagenarium. Apenas o isolado PE6 apresentou dimensões maiores em comprimento e largura que as utilizadas na classificação. Os demais isolados apresentam dimensões menores que as descritas, levantando a hipótese de serem identificados como C. gloeosporioides. O teste Cluster realizado revelou a formação de 7 grupos, onde observa-se que todos isolados do grupo 1, três isolados do grupo 2, um isolado do grupo 3 e o único isolado do grupo 5, se apresentam dentro da faixa de classificação, os demais grupos (4, 6 e 7) são formados por isolados que não se encaixam nas descrições (Tabela 6).

A pesar dos isolados apresentarem médias relação comprimento/largura variando entre 2,35 e 3,94, analisando-se apenas a relação $\mathrm{C} / \mathrm{L}$ dos isolados que se encontram dentro da faixa de classificação utilizada, conclui-se que a maior relação é de 3,60, e que a média para relação entre estes isolados é de 2,91. Ao aferir as dimensões de conídios de C. gloeosporioides em seringueira, Furtado et al. (1999), observou médias de relações comprimento/largura que variavam de 3,16 a 4,15, considerando mais ovalados os isolados que apresentavam relações C/L menores. Couto \& Meneses (2004) consideraram que os isolados que apresentaram relação $\mathrm{C} / \mathrm{L}$ menor produziam conídios menores em relação aos outros isolados de C. musae. A avaliação do tamanho dos conídios pela relação $\mathrm{C} / \mathrm{L}$ parece ser um bom parâmetro, indicando que quanto maior o quociente dessa relação, os conídios são mais longos e delgados e vice-versa (Veras et al., 1997). Considerando-se que, mediante a relação média dos isolados ser de 2,91, os isolados possuem formas mais oblongas que longas. Formas longas caracterizam isolados de C. gloeosporioides. Através da morfologia dos conídios, Furtado et al. (1999) diferenciaram os isolados C. gloeosporioides de folha e haste que se 
apresentaram mais longos, dos isolados de frutos e painel, que se apresentaram com dimensões intermediárias.

Tabela 6. Comprimento, largura, e relação C/L de conídios de isolados de C. lagenarium

\begin{tabular}{|c|c|c|c|c|c|c|c|c|c|c|c|}
\hline \multirow{3}{*}{$\frac{\text { Isolados }}{\mathrm{CH} 1^{1}}$} & \multirow{3}{*}{$\frac{\text { Grupos }}{2}$} & \multicolumn{4}{|c|}{ Largura } & \multicolumn{4}{|c|}{ Comprimento } & \multirow{2}{*}{\multicolumn{2}{|c|}{ Relação C/L }} \\
\hline & & \multicolumn{2}{|c|}{ Media } & \multirow{2}{*}{$\frac{\text { Min. }}{2,50}$} & \multirow{2}{*}{$\frac{\text { Máx. }}{4,17}$} & \multicolumn{2}{|c|}{ Media } & \multirow{2}{*}{$\begin{array}{l}\text { Min. } \\
6,66\end{array}$} & \multirow{2}{*}{$\begin{array}{c}\text { Máx. } \\
\text { 18,33 }\end{array}$} & & \\
\hline & & $3,69^{2}$ & $\mathrm{j}$ & & & 12,50 & ef & & & 3,29 & bcdefgh \\
\hline СH3 & 4 & 2,25 & l & 1,78 & 3,33 & 7,77 & g & 3,11 & 15,54 & 3,49 & abcde \\
\hline $\mathrm{CH} 4$ & 7 & 2,28 & l & 1,55 & 4,44 & 5,34 & $\mathrm{~h}$ & 2,89 & 8,66 & 2,35 & $\mathrm{k}$ \\
\hline PE1 & 1 & 4,75 & $\mathrm{~cd}$ & 3,33 & 5,83 & 13,99 & abcd & 8,33 & 16,66 & 2,92 & fghij \\
\hline PE3 & 1 & 5,08 & bc & 4,17 & 6,66 & 15,10 & b & 13,33 & 16,66 & 2,94 & fghij \\
\hline PE4 & 1 & 4,62 & defg & 4,17 & 5,00 & 14,70 & abc & 11,66 & 16,66 & 3,18 & cdefghi \\
\hline PE5 & 1 & 5,28 & b & 4,17 & 5,83 & 14,65 & abc & 10,00 & 16,66 & 2,79 & ijk \\
\hline PE6 & 6 & 6,38 & $\mathrm{a}$ & 5,83 & 8,33 & 15,73 & $\mathrm{a}$ & 14,16 & 17,49 & 2,49 & jk \\
\hline CL5 & 2 & 2,98 & $\mathrm{k}$ & 2,50 & 4,17 & 11,88 & $\mathrm{f}$ & 10,00 & 13,33 & 3,94 & $\mathrm{a}$ \\
\hline CL7 & 1 & 4,93 & cd & 3,33 & 6,66 & 15,21 & b & 10,00 & 19,99 & 3,05 & efghi \\
\hline CL11 & 1 & 4,81 & cde & 4,17 & 6,66 & 14,45 & abc & 9,16 & 18,33 & 3,05 & efghi \\
\hline CL15 & 2 & 4,88 & $\mathrm{~cd}$ & 4,17 & 6,66 & 14,93 & b & 12,50 & 16,66 & 3,07 & efghi \\
\hline CL20 & 1 & 4,69 & def & 3,33 & 5,83 & 14,69 & abc & 10,83 & 19,16 & 3,12 & defghi \\
\hline CL22 & 1 & 4,70 & de & 4,17 & 5,83 & 14,86 & b & 9,16 & 18,33 & 3,19 & cdefghi \\
\hline CL41 & 1 & 4,36 & fgh & 4,17 & 5,00 & 14,79 & b & 11,66 & 16,66 & 3,40 & bcdef \\
\hline AB274 & 3 & 3,86 & ij & 3,33 & 4,17 & 13,08 & bcdef & 6,66 & 19,99 & 3,48 & abcde \\
\hline $\mathrm{AB} 1$ & 2 & 4,07 & hi & 3,33 & 5,83 & 11,78 & $\mathrm{f}$ & 9,16 & 13,33 & 2,90 & ghij \\
\hline AB2 & 1 & 4,28 & gh & 3,33 & 5,83 & 15,53 & $\mathrm{a}$ & 12,50 & 18,33 & 3,60 & abc \\
\hline AB3 & 1 & 5,08 & bc & 4,17 & 6,66 & 14,91 & b & 11,66 & 16,66 & 2,95 & fghij \\
\hline MA1 & 3 & 4,43 & efg & 3,33 & 5,83 & 12,56 & def & 10,83 & 14,99 & 2,81 & hijk \\
\hline MA2 & 2 & 4,00 & hi & 3,33 & 5,00 & 11,51 & $\mathrm{f}$ & 9,16 & 13,33 & 2,88 & ghij \\
\hline MA3 & 2 & 3,20 & $\mathrm{k}$ & 2,50 & 4,17 & 11,85 & $\mathrm{f}$ & 7,50 & 16,66 & 3,78 & $a b$ \\
\hline ME1 & 3 & 3,83 & ij & 3,33 & 4,17 & 12,74 & cdef & 10,83 & 14,99 & 3,33 & bcdefg \\
\hline ME2 & 4 & 2,80 & $\mathrm{k}$ & 2,50 & 3,33 & 7,86 & g & 5,00 & 13,33 & 2,81 & hijk \\
\hline ME3 & 5 & 3,87 & ij & 3,33 & 5,00 & 14,06 & abcde & 10,83 & 16,66 & 3,60 & abcd \\
\hline CV (\%) & & & 3,085 & & & & 5,727 & & & & 5,731 \\
\hline
\end{tabular}

1 - $\mathrm{CH}$ =isolado de chuchu; $\mathrm{PE}=$ =isolado de pepino; $\mathrm{CL}=$ =isolado de pepino; $\mathrm{AB}=$ =isolado de abóbora; $\mathrm{MA}=$ =isolado de melancia; ME=isolado de melão. 2 - micrômetros

\subsubsection{Caracterização dos apressórios de C. lagenarium}

\subsection{Caracterização quanto à forma do apressório}

Os apressórios quando observados em microscópio óptico, apresentaram-se melanizados, formados por uma única célula, com presença de um septo separando-os do tubo germinativo, e variando em três formas predominantes: globosos, clavados, e 
lobulados ou irregulares. Os apressórios clavados foram encontrados em todos isolados analisados, variando de 8 a 76\% dos apressórios avaliados. Os apressórios globosos foram encontrados em 16 dos 17 isolados analisados variando de 16 a 76\% dos apressórios avaliados. Os apressórios lobados ou irregulares foram encontrados em 14 dos 17 isolados analisados, no entanto compunham de 8 a $80 \%$ do total de apressórios analisados (Tabela 7). Os isolados CH3, CH4 e CL11, apesar de terem germinado e formado hifas a partir dos esporos, não apresentaram formação de apressórios nas condições do experimento. Demais isolados que não são apresentados não foram avaliados.

Tabela 7. Caracterização morfológica dos apressórios de C. lagenarium

\begin{tabular}{lccc}
\hline Isolados & Globosos & Clavados & Lobulados \\
\hline PE3 & $16^{2}$ & 72 & 12 \\
PE5 & 52 & 8 & 40 \\
PE6 & 60 & 32 & 8 \\
CL5 & 0 & 20 & 80 \\
CL7 & 28 & 12 & 60 \\
CL15 & 35 & 52 & 13 \\
CL20 & 52 & 16 & 32 \\
CL22 & 32 & 20 & 48 \\
AB1 & 32 & 16 & 52 \\
AB2 & 48 & 24 & 28 \\
AB3 & 16 & 40 & 44 \\
MA1 & 36 & 40 & 24 \\
MA3 & 16 & 32 & 52 \\
ME1 & 24 & 76 & 0 \\
ME2 & 40 & 60 & 0 \\
ME3 & 24 & 20 & 56 \\
1- CH=isolado de chuchu; PE=isolado de pepino; CL=isolado de pepino; AB=isolado de abóbora; MA=isolado de melancia; \\
ME=isolado de melăo. 2 - percentagens.
\end{tabular}

A descrição para apressórios de C. lagenarium dada por Sutton (1992) compreende os formatos oval, clavado, e irregular. Em trabalho mais recente, Shen et al. (2001) descreve que os apressórios encontrados eram ocasionalmente clavados, a maioria oval e alguns levemente lobulados. No entanto, Sutton (1992) em sua descrição de apressórios para a espécie C. gloeosporioides cita as formas ovais, clavadas e levemente lobuladas, o que confunde a distinção das duas espécies por apresentarem 
formas muito semelhantes, senão a mesma, para formas de apressórios. Conclui-se que, a forma dos apressórios isoladamente não constitui uma boa característica para identificação ou caracterização da espécie C. lagenarium.

A pigmentação dos apressórios do gênero Colletotrichum está relacionada com a capacidade de penetração no tecido do hospedeiro. Deising et al., (2000) citam que isolados de Colletotrichum spp. tratados com inibidores da biossíntese de melanina são incapazes de penetrar no tecido do hospedeiro. Do mesmo modo, Kubo et al. (1982) trabalhando com isolados de C. lagenarium observaram uma relação entre a falta de capacidade para penetrar numa membrana de nitrocelulose com a pigmentação dos apressórios. Apresar de todos isolados que formaram apressórios apresentarem coloração castanha, devido presença de melanina, nem todos isolados que apresentaram estas características se mostraram virulentos à espécies de cucurbitáceas (Capítulo 2). No entanto, os isolados CH3, CH4 e CL11, que não apresentaram formação de apressórios nas condições do experimento, também não se mostraram virulentos às espécies de cucurbitáceas, sugerindo possível perda de virulência devido não produção de estrutura necessária à penetração.

\subsection{Caracterização quanto às dimensões do apressório}

As dimensões dos apressórios analisados variaram entre 4,21 a 11,10 $\mu \mathrm{m}$ de largura, 5,55 a 14,43 $\mu$ m de comprimento, e a relação entre o comprimento e a largura variou entre 1,12 a 1,49 (Tabela 8). Todos os isolados apresentaram apressórios com dimensões médias dentro da faixa descrita por Sutton (1992), cujo comprimento varia de 6,5 a $16 \mu \mathrm{m}$, e a largura varia de 5,5 a $10 \mu \mathrm{m}$ de comprimento. Da mesma forma que o formato de apressórios das espécies C. lagenarium e C. gloeosporioides não constitui uma boa característica para distinção entre elas, as dimensões (comprimento e largura) também não possibilitam tal distinção. A amplitude descrita, tanto para o comprimento, quanto para a largura dos apressórios de C. lagenarium pode ser sobreposta pela amplitude descrita para as mesmas dimensões de C. gloeosporioides (de 4 a $12 \mu \mathrm{m}$ de largura, e de 6 a $20 \mu \mathrm{m}$ de comprimento). 
Tabela 8. Comprimento, largura e relação C/L dos apressórios de isolados de C. lagenarium

\begin{tabular}{|c|c|c|c|c|c|c|c|c|c|c|c|}
\hline \multirow{3}{*}{$\begin{array}{l}\text { Isolados } \\
\mathrm{CH} 1^{1}\end{array}$} & \multirow{3}{*}{$\frac{\text { Grupos }}{3}$} & \multicolumn{4}{|c|}{ Largura } & \multicolumn{4}{|c|}{ Comprimento } & \multirow{2}{*}{\multicolumn{2}{|c|}{ Relação C/L }} \\
\hline & & \multicolumn{2}{|c|}{ Média } & \multirow{2}{*}{$\frac{\text { Min. }}{4,44}$} & \multirow{2}{*}{$\begin{array}{c}\text { Máx. } \\
6,66\end{array}$} & \multicolumn{2}{|c|}{ Média } & \multirow{2}{*}{$\begin{array}{l}\text { Min. } \\
5,99\end{array}$} & \multirow{2}{*}{$\frac{\text { Max. }}{8,21}$} & & \\
\hline & & $5,64^{2}$ & $\mathrm{i}$ & & & 6,88 & e & & & 1,22 & bcde \\
\hline PE3 & 2 & 7,49 & def & 6,77 & 8,60 & 9,74 & $a b$ & 8,94 & 12,27 & 1,30 & bc \\
\hline PE5 & 2 & 8,09 & bc & 7,43 & 8,88 & 9,22 & bc & 7,99 & 10,21 & 1,14 & de \\
\hline PE6 & 2 & 8,46 & $a b$ & 7,77 & 9,32 & 9,71 & $\mathrm{ab}$ & 7,77 & 12,21 & 1,15 & de \\
\hline CL5 & 2 & 6,88 & gh & 5,77 & 8,88 & 10,26 & $\mathrm{a}$ & 8,43 & 14,43 & 1,49 & $\mathrm{a}$ \\
\hline CL7 & 2 & 8,68 & $\mathrm{a}$ & 6,66 & 11,10 & 10,75 & $\mathrm{a}$ & 8,44 & 14,43 & 1,22 & bcde \\
\hline CL15 & 2 & 7,32 & efg & 6,32 & 8,54 & 9,60 & abc & 8,55 & 11,87 & 1,32 & bc \\
\hline CL20 & 2 & 7,73 & cde & 6,66 & 8,88 & 8,72 & $\mathrm{~cd}$ & 7,77 & 9,99 & 1,12 & e \\
\hline CL22 & 2 & 7,77 & cde & 5,99 & 8,88 & 8,94 & bcd & 6,66 & 11,1 & 1,15 & de \\
\hline AB1 & 1 & 6,65 & h & 5,55 & 7,77 & 8,07 & d & 6,66 & 9,32 & 1,21 & de \\
\hline AB2 & 1 & 7,03 & fgh & 5,77 & 8,44 & 7,97 & d & 6,44 & 8,88 & 1,13 & d \\
\hline AB3 & 1 & 7,03 & fgh & 5,55 & 8,88 & 8,14 & d & 5,99 & 10,66 & 1,15 & de \\
\hline MA1 & 3 & 5,54 & $\mathrm{i}$ & 4,21 & 7,77 & 6,71 & e & 5,55 & 9,10 & 1,21 & cde \\
\hline MA3 & 2 & 7,95 & bcd & 6,66 & 8,88 & 9,54 & abc & 7,10 & 11,10 & 1,20 & cde \\
\hline ME1 & 2 & 8,03 & bc & 7,55 & 8,88 & 9,72 & $a b$ & 8,88 & 9,99 & 1,21 & cde \\
\hline ME2 & 1 & 5,89 & i & 4,44 & 7,77 & 8,04 & d & 6,66 & 9,99 & 1,36 & b \\
\hline ME3 & 1 & 6,94 & gh & 5,55 & 8,88 & 8,83 & bcd & 6,66 & 11,10 & 1,27 & bcd \\
\hline CV(\%) & & & 2,827 & & & & 4,284 & & & & 4,344 \\
\hline
\end{tabular}

Comprimento e largura de apressórios até recentemente eram largamente utilizados nos estudos de taxonomia para todo o gênero Colletotrichum (Vinnere, 2004). De acordo com Sutton (1992), apressórios de C. gloeosporioides apresentam dimensões ligeiramente maiores que apressórios de C. acutatum, no entanto, Vinnere (2004) enfatiza que, na prática, a diferenciação destas duas espécies utilizando-se apenas as dimensões dos apressórios é muito difícil, proporcionando resultados não muito claros e confiáveis. Além disso, Simmonds (1965) menciona que as espécies de Colletotrichum utilizadas em seus estudos não apresentaram diferenças significativas quanto às dimensões dos apressórios, necessitando assim de estudos mais detalhados.

\subsection{Conclusões}

O crescimento micelial e a esporulação apresentaram melhores respostas para maioria dos isolados quando cultivados em meio de Aveia. 
O crescimento micelial apresenta resultados reprodutíveis variando-se os meios de cultura, no entanto é muito variável entre os isolados.

A esporulação é variável tanto entre os isolados, quanto entre os meios de cultura analisados.

As características culturais como coloração e topografia de colônia, e formação de setores, apresentaram grande variabilidade, inviabilizando a identificação da espécie por meio destas.

A coloração da massa conidial apresentou pouca variação, sendo uma característica que poderia identificar a espécie C. lagenarium, no entanto nem todos isolados a apresentaram.

A maioria dos isolados apresentaram conídios e apressórios com formatos e dimensões dentro do esperado para a espécie. Alguns isolados que apresentaram dimensões inferiores, e poderiam ser identificados como C. gloeosporioides devido proximidade de características.

As características morfológicas não se apresentaram como bons parâmetros para identificação da espécie C. lagenarium, pois se assemelham às características de outras espécies, principalmente C. gloeosporioides. 


\section{CARACTERIZAÇÃO PATOGÊNICA E IDENTIFICAÇÃO MOLECULAR DE ISOLADOS DE Colletotrichum lagenarium}

\section{Resumo}

A antracnose, causada por Colletotrichhum lagenarium, provoca sérios prejuízos nas culturas de cucurbitáceas. No Brasil, a antracnose ocorre em praticamente todas regiões onde se cultiva qualquer espécie de cucurbitácea, sendo constatada em plantações de abobrinha, chuchu, melancia, melão e pepino. O presente trabalho visa a caracterização patogênica e a identificação molecular dos isolados de C. lagenarium, oriundos de plantas da família Cucurbitaceae. Os isolados foram obtidos através de isolamento de tecidos de cucurbitáceas que apresentavam sintomas de antracnose. A caracterização patogênica envolveu a avaliação da virulência de todos os isolados em inoculações cruzadas com pepino, melão, melancia, abóbora e chuchu, além da avaliação do período de incubação, do período latente e do índice de crescimento da lesão. A identificação molecular compreendeu a análise de PCR, utilizando "primer" específico para C. lagenarium, para auxílio na identificação da espécie. Dos 25 isolados testados nas inoculações cruzadas, apenas 14 se apresentaram virulentos aos hospedeiros testados. Não foi encontrada correspondência entre a virulência do isolado e o hospedeiro de origem, o local de coleta, suas características culturais ou morfológicas. Cada isolado apresentou um comportamento diferente perante os demais, quando se considerou a gama de hospedeiros a ele suscetíveis, e ao seu comportamento quanto aos períodos latente e de incubação, e ao índice de crescimento de lesão. Quanto aos 
isolados que não apresentaram virulência a nenhum hospedeiro testado, acredita-se que a perda da virulência esteja relacionada com o período em que os isolados permaneceram armazenados em meio BDA, imersos em óleo mineral. O período de incubação variou de dois a sete dias, e período latente variou de três a nove dias, resultados não discordantes aos encontrados na literatura. O índice de crescimento de lesão variou de 0,5 a 4,9mm/dia, sugerindo que exista variabilidade na agressividade dos isolados. Contudo, não foi observada correlação entre os períodos latentes e de incubação, e o índice de crescimento de lesão. Através da identificação molecular, cinco isolados puderam ser identificados pelo “primer” específico utilizado, contudo não foi encontrada correspondência entre a identificação molecular e as caracterizações cultural, morfológica e patogênica.

Pathogenic characterization and molecular identification of Colletotrichum Iagenarium isolates

\section{Summary}

Anthracnose, caused by Colletotrichum lagenarium, causes severe losses in the cucurbitaceous crops. In Brazil, anthracnose occurs in practically all regions where species of cucurbitaceous plants are cultivated, mainly in pumpkin, chayote, watermelon, melon and cucumber fields. The aim of this work was to determine the pathogenic characterization and the molecular identification of $C$. lagenarium isolates, isolated from plants of the Cucurbitaceae family. The isolates used in this study were obtained through isolation from plants presenting symptoms of Anthracnose. The pathogenic characterization involved the evaluation of the virulence of all isolates on cross inoculations with cucumber, melon, watermelon, pumpkin and chayote, evaluation of the incubation period, the latent period and lesion growth. For the molecular identification PCR analysis was used, with specific primer for C. lagenarium, to assist the identification of the species. From the 25 isolates tested in the cross inoculations, only 14 were virulent to the tested host plants. Correspondence was not found between the virulence of the isolates and the host plants origin, local of origin, and the cultural and morphological characteristics. Analyzing the variability of susceptible host 
plants, the inoculation and latent periods, and lesion growth, each isolate showed a different behavior compared to the others. The virulence loss of some isolates could be caused by the period that they had been stored on PDA medium, immersed in mineral oil. The incubation period varied from two to seven days, and the latent period varied from three to nine days. Lesion growth varied from 0.5 to $4.9 \mathrm{~mm} /$ day, suggesting that exists variability in the agressiveness of the isolates. However, it was not observed correlation between the latent and incubation periods, as well as in lesion growth. Five isolates were identified to the pair of primers used, although correspondence was not found among the molecular identification and the cultural, morphological and pathogenic characterization.

\subsection{Introdução}

Entre as doenças que ocorrem em cucurbitáceas, a antracnose, causada por Colletotrichum lagenarium ((Pass.) Ell. \& Hals.) (sin. C. orbiculare (Berk. \& Mont) Arx), é provavelmente uma das principais, em várias partes do mundo. Nas cucurbitáceas, como pepino, chuchu, melão e melancia, a antracnose é muito freqüente e causa prejuízos bastante elevados. O patógeno afeta toda parte aérea da planta, em qualquer fase do seu desenvolvimento, e causa desfolha precoce, com perda de vitalidade ou morte. Quando a doença incide sobre os frutos, os deprecia comercialmente, chegando a inutilizá-los para o consumo. Quando o cultivo é feito em épocas quentes e úmidas, a doença pode se tornar fator limitante para a cultura. (Agrios, 1997; Kurozawa \& Pavan, 1997; Thompson \& Jenkins, 1985; Sitterly \& Keinath, 1996).

A patogenicidade específica a um determinado hospedeiro, ou grupo de hospedeiros, é constantemente utilizada em chaves de classificação para espécies de Colletotrichum (Baxter et al. 1983; Sutton, 1980). Contudo, em grande parte dos casos, a distinção entre espécies de Colletotrichum é feita com base em características morfológicas dos esporos e apressórios (Sutton, 1992).

Atualmente são reconhecidos três grandes grupos do gênero Colletotrichum, baseados nas espécies C. gloeosporioides, C. acutatum e C. orbiculare, às quais são agregadas as demais espécies (Cannon et al., 2000). Dados moleculares e culturais indicam que muitas espécies do gênero Colletotrichum, particularmente aquelas que 
apresentam infecção intracelular hemibiotrófica, poderiam ser agrupadas junto à espécie C. orbiculare (Bailey et al., 1996; Sherriff et al., 1994; Sreenivasaprasad et al., 1996).

Além dos métodos tradicionais de caracterização, análises cultural e morfológica, outros métodos vêm sendo empregados recentemente com maior freqüência, entre eles a patogenicidade, os grupos de compatibilidade vegetativa, a análise isoenzimática, e os métodos moleculares, como RAPD e RFLP. Recentemente observa-se a necessidade de utilizar diferentes métodos de caracterização aliados aos métodos moleculares, principalmente devido a grande variabilidade genética encontrada dentro do gênero Colletotrichum (Menezes, 2002).

Por meio de testes de patogenicidade em ramos e frutos de macieira, Carvalho et al. (2000) caracterizaram isolados de C. gloeosporioides e C. acutatum, ambos associados à podridão amarga da maçã. As inoculações em frutos revelaram que as duas espécies são capazes de causar podridões, com algumas diferenças na sintomatologia. Porém, somente os isolados da espécie C. gloeosporioides foram patogênicos às folhas de macieira, sendo, portanto, essa a espécie causal da mancha de Glomerella em macieiras no Brasil. Bernstein et al. (1995), compararam setenta e dois isolados de Colletotrichum isolados de pêssego, maçã, pecan, morango e abacate. Os isolados puderam ser separados por coloração da colônia em dois grupos, contudo, apesar das diferenças culturais, os testes de patogenicidade em frutos destacados de pessegueiro revelaram não ser possível distinguir os sintomas causados pelas duas espécies. Os autores concluíram que ambas as espécies ocorrem indistintamente causando doenças em pêssego, maçã e pecan. No Brasil, em dois estudos semelhantes à esse último (Goes \& Kimati, 1997a;b), encontraram resultados semelhantes. Os autores verificaram que, tanto C. gloeosporioides como C. acutatum, ocorrem naturalmente em plantas cítricas com sintomas de queda prematura dos frutos. Da mesma forma, os isolados puderam ser separados a partir das características culturais, além de serem observadas diferenças na forma dos apressórios entre as duas espécies. Além dessas diferenças culturais e morfológicas, os resultados dos testes de patogenicidade revelaram que somente os isolados de C. acutatum reproduziram os sintomas de queda prematura dos frutos. 
Além da caracterização entre diferentes espécies de Colletotrichum, estudos de patogenicidade têm revelado também variabilidade dentro de uma mesma espécie, como é o caso do trabalho conduzido por Freeman et al. (1996). Trabalhando com isolados de C. gloeosporioides de amêndoa e de abacate, os autores realizaram inoculações cruzadas, em frutos destacados de ambas culturas. Os isolados provenientes de abacate provocaram intensidades semelhantes de doença em abacate e amêndoa, porém, os isolados de amêndoa foram bem menos agressivos quando inoculados em abacate. Isso revelou um certo grau de especialização nos isolados provenientes de amêndoa. Também no Brasil já se verificou variabilidade na capacidade patogênica de $C$. gloeosporioides. Furtado et al. (1999), estudando a variabilidade entre isolados de folha, painel, haste e frutos de seringueira, verificaram diferenças na patogenicidade quando foram inoculados discos de folíolos de seringueira em condições de laboratório. Da mesma forma, Assis et al. (2001), verificaram diferenças na agressividade entre seis isolados de C. gloeosporioides de frutos de mangueira por meio de testes de patogenicidade em frutos destacados das variedades Espada, Rosa e Tommy Atkins. Além disso, esses isolados se diferenciaram quanto ao crescimento micelial e esporulação quando diferentes fontes de carbono foram incorporadas ao meio de cultivo. O conhecimento da variação da patogenicidade deve ser o passo inicial de todo e qualquer trabalho de melhoramento de cucurbitáceas visando a obtenção de variedades resistentes a antracnose, e também a qualquer recomendação de rotação de culturas pertencente à família Cucurbitaceae (Lisboa, 1962).

Através de testes de inoculação cruzada e marcadores moleculares, Hayden et al. (1994) conseguiram separar o biótipo de infectivo a manga dos demais isolados do complexo C. gloeosporioides. Mills et al. (1992), conseguiram separar isolados de C. gloeosporioides oriundos de manga de demais isolados de C. gloeosporioides apenas utilizando marcadores moleculares.

Técnicas moleculares tem sido utilizadas para diversos fungos, porém, particularmente para o gênero Colletotrichum, elas têm auxiliado grandemente na demonstração da variabilidade inter e intraespecífica. As técnicas mais empregadas com essa finalidade são o "Restriction Fragment Length Polymorphism” (RFLP) e "Random 
Amplified Polymorphic DNA” (RAPD). Braithwaite et al. (1990), utilizaram a técnica de RFLP para demonstrar a divergência genética entre C. gloeosporioides tipos A e B, duas populações com diferenças morfológicas, patogênicas e bioquímicas que ocorrem em Stylosanthes, na Austrália. Utilizando essa técnica, esses autores revelaram que ambas as populações são geneticamente homogêneas, porém distintas entre si. O fato de não ocorrerem as fases perfeitas de nenhuma dessas populações na Austrália, explica a uniformidade genética intrapopulacional e descarta a possibilidade de especialização patogênica dessa espécie. Dessa forma, os autores concluem que a existência de duas populações tão diferentes só pode ser explicada por duas diferentes introduções do patógeno no país.

A técnica de RAPD foi utilizada no Brasil, numa série de trabalhos, para caracterizar isolados de C. lindemuthianum do feijoeiro (Vilarinhos et al., 1995; AlzateMarin et al., 1997; Mesquita et al., 1998). Nesses trabalhos, foram utilizados diversos isolados do fungo, numa tentativa de discriminar as diferentes raças por meio da técnica de RAPD. Apesar dos resultados não terem permitido o mesmo agrupamento obtido com os testes de inoculação em variedades diferenciadoras, a técnica mostrou bom potencial na caracterização da variabilidade patogênica de $C$. lindemuthianum. Além dessa espécie, o RAPD já foi utilizado, com sucesso, para caracterizar a variabilidade de $C$. graminicola (Guthrie et al., 1992; Browning et al., 1999), C. orbiculare (Correll et al., 1993) e C. gloeosporioides (Alahakoon et al., 1994; Hayden et al., 1994; Kelemu et al., 1999).

O presente trabalho visa a caracterizar patogenicamente e realizar a identificação molecular dos isolados de Colletotrichum lagenarium, oriundos de plantas da família Cucurbitaceae.

\subsection{Material e Métodos}

\subsubsection{Caracterização patogênica}

Os isolados de C. lagenarium foram obtidos de plantas da família das cucurbitáceas, provenientes de diferentes localidades. Após o isolamento e formação de 
colônia, a manutenção dos isolados foi feita tubos de ensaio contendo meio BDA inclinado, imersos em óleo mineral Nujol ${ }^{\circledR}$ autoclavado.

Os isolados de C. lagenarium, independentemente do hospedeiro em que foram obtidos, foram inoculados em plântulas de pepino (Cucumis sativus), melão (Cucumis melo), melancia (Citrullus lanatus) e abóbora (Cucurbita pepo), e plantas com 2 pares de folhas expandidas de chuchu (Sechium edule). Para o teste de inoculação cruzada, foram utilizadas sementes de pepino cv. Rubi, de melão cv. Amarelo, de abóbora cv. Menina Brasileira, e de melancia cv. Crimson Sweet, todas sem tratamento químico de sementes, a fim de não haver interferência nos resultados. Para testes com plantas de chuchu, foram coletados frutos, que apresentavam início de brotação, na área experimental do Departamento de Fitopatologia, e na área experimental do Departamento de Horticultura. Para observar a possível existência de diferenças quanto à suscetibilidade ao C. lagenarium em diferentes cultivares de pepino, foi realizado um ensaio complementar com oito cultivares de pepino e oito isolados do fungo. Os cultivares testados foram: Rubi, Esmeralda tipo Caipira, Eclipse, Conserva SMR-58, Beit Alpha, Fortuna, Safira (Híbrido F1) e Híbrido Pioneiro, todos sem tratamento químico de sementes.

Foram realizados dois ensaios com as plântulas de pepino, melão, melancia e abóbora. No primeiro ensaio as plântulas testadas foram semeadas em copos plásticos de $50 \mathrm{ml}$ contendo substrato para semeadura de hortaliças "Plantimax", acondicionadas em caixas plásticas de 37cm de comprimento, por $26 \mathrm{~cm}$ de largura, por $12 \mathrm{~cm}$ de altura, e mantidas na casa de vegetação até a geminação e expansão dos cotilédones. Posteriormente, realizou-se a inoculação colocando-se uma gota de $20 \mu$ de suspensão de esporos calibrada em $10^{5}$ conídios $/ \mathrm{ml}$ em cada cotilédone. Plântulas inoculadas apenas com água destilada serviram como controle. Dentro da bandeja foi adicionado um volume de $200 \mathrm{ml}$ de água destilada para auxiliar a manutenção da umidade. Logo após a inoculação as bandejas foram cobertas e vedadas com plástico e fita adesiva, a fim de estabelecer uma câmara úmida durante 48 horas após a inoculação. A partir da inoculação até o final das avaliações, as plântulas foram mantidas dentro do Laboratório de Micologia, sob iluminação artificial (lâmpadas fluorescentes), e temperatura $24 \pm 2$ 
${ }^{\circ} \mathrm{C}$, para o desenvolvimento e avaliação dos sintomas. Foram utilizadas seis repetições para cada isolado, em delineamento inteiramente casualizado.

No segundo ensaio realizado com as plântulas de pepino, melão, melancia e abóbora, as mesmas foram semeadas em bandejas de 128 células, preenchidas com substrato para semeadura de hortaliças "Plantimax", e mantidas em casa de vegetação até completa expansão dos cotilédones. Posteriormente, realizou-se a inoculação colocando-se uma gota de $20 \mu$ de suspensão de esporos calibrada em $10^{5}$ conídios/ml em cada cotilédone. Plântulas inoculadas apenas com água destilada serviram como controle. As bandejas com as plântulas inoculadas foram acondicionadas em câmara úmida durante 48 horas, onde uma camada de serragem umedecida cobrindo o piso, e um atomizador em funcionamento constante, mantinham a umidade relativa do ar próxima a 100\%. Após o período de 48 horas em câmara úmida, as bandejas com as plântulas foram mantidas em casa de vegetação para o desenvolvimento e avaliação dos sintomas. O ensaio foi composto por oito repetições para cada isolado, em delineamento inteiramente casualizado.

Para avaliação da virulência em plantas de chuchu, os frutos com brotação iniciada, foram plantados em vasos com capacidade para um litro, utilizando-se solo esterilizado como substrato, e mantidos em casa de vegetação para desenvolvimento das plantas. As plantas ao apresentarem duas folhas verdadeiras expandidas, foram inoculadas colocando-se uma gota de $20 \mu \mathrm{l}$ de suspensão de esporos, calibrada em $10^{5}$ conídios/ml em cada folha. Folhas inoculadas apenas com água destilada serviram como controle. Os vasos com as plantas inoculadas foram acondicionados em câmara úmida durante 48 horas, onde uma camada de serragem umedecida cobrindo o piso, e um atomizador em funcionamento constate, mantinham a umidade relativa do ar próxima a 100\%. Após o período de 48 horas em câmara úmida, os vasos com as plantas foram mantidos em casa de vegetação para o desenvolvimento e avaliação dos sintomas. Foram utilizadas oito repetições por isolado, em delineamento inteiramente casualizado.

Para todos ensaios de inoculação cruzada, e para o ensaio de virulência em pepino, as avaliações foram realizadas diariamente, após retirada da câmara-úmida e prosseguindo-se durante 15 dias. Foram avaliados a virulência, o período de incubação, 
o período latente e a velocidade de desenvolvimento da lesão. O período de incubação foi avaliado mensurando-se o período decorrido da inoculação até o surgimento da lesão. O período latente foi avaliado mensurando-se o período decorrido da inoculação até a esporulação do patógeno. A esporulação foi constatada através de análise visual com auxílio de lupa. A velocidade de desenvolvimento da lesão foi avaliada mensurando-se as lesões com auxílio de um paquímetro, no sentido da nervura central das folhas ou cotilédones, e no sentido perpendicular à nervura central, posteriormente transformados em índice diário de crescimento de lesão (IDCL).

\subsubsection{Identificação Molecular}

\subsubsection{Extração de DNA}

Utilizou-se protocolo aprimorado para extração de DNA de Martins \& Bacci Júnior (2001), adaptado para Colletotrichum, onde 8 discos de 5 mm de diâmetro foram retirados de culturas crescidas em meio de Aveia, durante sete dias.

Para extração de DNA total, os micélios foram triturados e homogeneizados com $600 \mu \mathrm{l}$ de tampão TNES (250mM Tris-base pH 7,5, 2M NaCl $2,100 \mathrm{mM}$ EDTA, 2,5\% SDS), dentro de tubos de $1,5 \mathrm{ml}$, esterilizados, com auxílio de um bastão de vidro de ponta cônica. O homogeneizado foi incubado por 3 horas a $55^{\circ} \mathrm{C}$ em banho-maria. Adicionou-se $200 \mu \mathrm{l}$ de $\mathrm{NaCl} 25 \mathrm{M}$ às amostras e agitou-se durante 15 segundos em agitador de tubos. Centrifugaram-se as amostras por 3 minutos a 14000G. O sobrenadante foi extraído com cuidado para não carregar partículas de micélio, e transferido para um novo tubo de $1,5 \mathrm{ml}$ com $600 \mu \mathrm{l}$ de isopropanol. As amostras foram invertidas gentilmente por 30 vezes, para precipitação do DNA, e posteriormente foram centrifugadas por 3 minutos a 14000G. O DNA formou um "pellet” no fundo do tubo e o sobrenadante foi descartado. Depois de seco em temperatura ambiente, o "pellet" de DNA foi ressuspendido com $600 \mu$ de etanol $70 \%$, através de gentil inversão do tubo por 30 vezes. As amostras foram novamente centrifugadas a 14000G durante 3 minutos, posteriormente foi descartado o sobrenadante e o "pellet" de DNA foi seco em temperatura ambiente. Depois de seco o DNA foi dissolvido em $25 \mu$ l de TE (1M Tris- 
HCl pH 8,0, 500mM EDTA pH 8,0), e tratado com adição de $3 \mu l$ de RNAse, com incubação por 30 minutos em banho-maria a $37{ }^{\circ} \mathrm{C}$. O DNA foi quantificado em espectrofotômetro medindo-se a absorbância no comprimento de onda de 260nm, e foi analisada sua qualidade através da razão obtida das O.D. 260/280, conforme descrito por Sambrook et al.(1989). Posteriormente, as amostras de DNA foram diluídas para concentração de $20 \mu \mathrm{g} / \mu \mathrm{l}$, e estocadas a $-10^{\circ} \mathrm{C}$.

\subsubsection{Reação de PCR}

A identificação molecular dos isolados de $C$. lagenarium foi realizada através de PCR (Polymerase Chain Reaction), utilizando o par de “primers” CoINT (5'GCTCCCGGTAAAAGGG-3’) e ITS4 (5’-TCCTCCTATTGATATGC-3’), provenientes da Invitrogen Brasil Custom Technologies. O "primer” CoINT, específico a $C$. lagenarium, foi desenhado a partir dos resultados do seqüenciamento da região ITS1 (Mills et al, 1992), que além de apresentar alta conservação, também apresenta-se variável perante as espécies de Colletotrichum (Mills et al., 1992, 1994).

No entanto, o DNA genômico obtido da extração não apresentou boa qualidade, e as reações utilizando o DNA genômico não apresentaram bons resultados. Optou-se então por realizar uma amplificação da região ITS utilizando o par de "primers" universais ITS4 e ITS5 (5'-GGAAGTAAAAGTCGTAACAAGG-3'), obtendo-se assim no produto de reação um DNA de qualidade superior (White et al., 1990). O Produto da reação foi então utilizado na reação de PCR com o par de "primers” específico à $C$. lagenarium. Como controle negativo, foi utilizado um isolado de C. gloeosporioides, oriundo de frutos de pimentão, cuja identificação molecular já era conhecida.

Os procedimentos para as reações de PCR foram basicamente aqueles descritos por Willians et al. (1990). O processo foi dividido em duas etapas. Na primeira etapa foi realizada a reação que utilizou os "primers" ITS4 e ITS5, e nesta etapa foi utilizado o DNA genômico, o que resultou na amplificação da região ITS. Na segunda etapa foi realizada a reação que utilizou os primes CoINT e ITS4, no entanto foi utilizado o produto da amplificação da reação da primeira etapa como amostra de DNA. Foram 
utilizados tubos de $0,5 \mathrm{ml}$ para as reações, que contiveram 1 x Tampão de PCR, 0,5mM $\mathrm{MgCl}_{2}, 2,0 \mathrm{mM}$ de cada um dos quatro dNTP, 5ng de cada "primer” empregado, 1,5 $\mathrm{l}$ de DNA, 14,37 $\mu$ l de água miliQ autoclavada, 0,65 unidades de Taq DNA polimerase, totalizando um volume de $25 \mu \mathrm{l}$. O mesmo procedimento foi adotado para as duas etapas.

As amplificações para as ambas reações ocorreram em termociclador, programado para 35 ciclos a $94{ }^{\circ} \mathrm{C}$ por 1 minuto, $52{ }^{\circ} \mathrm{C}$ por 2 minutos, e $72{ }^{\circ} \mathrm{C}$ por 2 minutos, adaptado de Kelemu et al. (1999).

Alíquotas de $6 \mu \mathrm{l}$ dos produtos da reação e do marcador molecular $1 \mathrm{~Kb}$ DNA Ladder, foram adicionados de $6 \mu l$ de tampão de carregamento (Blue Juice), e homogeneizados sobre parafilme. Os produtos de PCR e o marcador molecular foram separados em gel de agarose a $1 \%$ em TBE $(0,1 \mathrm{M}$ de Tris- $\mathrm{HCl}, 0,1 \mathrm{M}$ de ácido bórico, 0,02 mM de EDTA, pH 8,3), numa voltagem aproximada de 120 volts. O gel foi colorido com brometo de etídio durante 10 minutos e fotografado em transiluminador sob luz UV.

A avaliação da PCR considerou como identificação positiva para a espécie $C$. lagenarium, a presença de banda com peso molecular de aproximadamente 600 pares de bases, nas reações onde se utilizou o "primer" CoINT.

\subsection{Resultados e Discussão}

\subsubsection{Caracterização patogênica de C. lagenarium}

Quanto à virulência dos isolados de C. lagenarium, apenas 14 dos 25 isolados inoculados em pepino, melão, melancia, abóbora e chuchu causaram lesões nas plantas (Tabela 09). Acredita-se que a perda da virulência de 11 isolados, entre eles os de pepino, esteja relacionada com o período em que os isolados permaneceram armazenados em meio BDA, imersos em óleo mineral (Tabela 1). Mesmo aumentandose o número de cultivares de pepino, buscando verificar a ocorrência de reação resistência a partir dos cultivares testados em ensaio adicional, os isolados de pepino continuaram não produzindo lesões. 
Entre os isolados de chuchu, apenas o isolado $\mathrm{CH} 1$ produziu lesões em plantas de chuchu, porém não produziu lesões nas outras espécies testadas. Rego et al. (1995b) também observaram baixa virulência para isolados oriundos de chuchu quando inoculados em outras cucurbitáceas. Além do isolado CH1, o isolado ME3 também produziu lesões apenas em seu hospedeiro de origem. Isolados de Colletotrichum spp. que se comportam mais virulentos aos seus hospedeiros de origem, que a outros hospedeiros já foram descritos por diversos autores (Lima Filho et al., 2003; Peres et al., 2002; Hayden et al., 1994), chegando a sugerir a existência de grupos de especialização patogênica (Munis et al., 1998). Contudo, entre os isolados testados, os isolados CL20, AB3 e MA3 se apresentaram virulentos a outros hospedeiros que não os de sua origem, indo contra aos resultados encontrados para $\mathrm{CH} 1$ e ME3.

Com exceção do isolado CL20 que produziu lesões apenas em plântulas de melancia, os demais isolados de pepino causaram lesões em plântulas de pepino, melancia e melão.

Os isolados de abóbora AB1 e AB2 apresentaram-se virulentos ao seu hospedeiro, no entanto o isolado $\mathrm{AB} 3$ não se mostrou virulento a plantas de abóbora, mas sim a plantas de melão, melancia e chuchu. Os três isolados de abóbora apresentaram-se virulentos a melão, além do isolado AB1 também se apresentar virulento a pepino e melancia.

Entre os isolados de melancia, o isolado MA1 foi virulento a pepino, melão, melancia, e chuchu, o isolado MA2 foi virulento a pepino, melão e melancia, e o isolado MA3 foi virulento apenas a pepino. Já entre os isolados de melão, todos foram virulentos a melão, no entanto o isolado ME1 também se apresentou virulento a pepino, e o isolado ME2 se apresentou virulento a pepino, melancia e abóbora.

Não foi encontrado nenhum isolado que se apresentasse virulento à todos hospedeiros ao mesmo tempo. No entanto, alguns isolados se apresentaram virulentos a até quatro hospedeiros diferentes, o que é relevante no momento da escolha de uma cultura para rotação com espécies da família Cucurbitaceae, e na eliminação de plantas voluntárias desta família, para evitar fontes de inóculo. 
Tabela 9. Inoculação cruzada de isolados de Colletotrichum lagenarium em pepino, melão, melancia, abóbora e chuchu

\begin{tabular}{|c|c|c|c|c|c|}
\hline \multirow{2}{*}{ Isolados } & \multicolumn{5}{|c|}{ Reação de Virulência } \\
\hline & Pepino & Melão & Melancia & Abóbora & Chuchu \\
\hline $\mathrm{CH}^{1}$ & -2 & - & - & - & + \\
\hline CH3 & - & - & - & - & - \\
\hline $\mathrm{CH} 4$ & - & - & - & - & - \\
\hline PE1 & - & - & - & - & - \\
\hline PE3 & - & - & - & - & - \\
\hline PE4 & - & - & - & - & - \\
\hline PE5 & - & - & - & - & - \\
\hline PE6 & - & - & - & - & - \\
\hline CL5 & ++ & ++ & ++ & - & - \\
\hline CL7 & - & - & - & - & - \\
\hline CL11 & - & - & - & - & - \\
\hline CL15 & ++ & ++ & - & - & - \\
\hline CL20 & - & - & + & - & - \\
\hline CL22 & + & + & - & - & - \\
\hline CL41 & - & - & - & - & - \\
\hline AB274 & - & - & - & - & - \\
\hline $\mathrm{AB} 1$ & + & + & + & + & - \\
\hline AB2 & - & + & - & + & - \\
\hline AB3 & - & ++ & ++ & - & + \\
\hline MA1 & ++ & ++ & ++ & - & + \\
\hline MA2 & ++ & ++ & ++ & - & - \\
\hline MA3 & ++ & - & - & - & - \\
\hline ME1 & ++ & ++ & - & - & - \\
\hline ME2 & ++ & ++ & ++ & ++ & - \\
\hline ME3 & - & ++ & - & - & - \\
\hline
\end{tabular}

Observou-se que plantas de pepino, melão e melancia se apresentam mais suscetíveis que as plantas de abóbora e chuchu. Wasilwa et al. (1993) reexaminando as raças 1 e 2 de $C$. orbiculare, com cultivares diferenciadoras de pepino, melão, melancia e abóbora, também observaram uma maior virulência dos isolados em melancia, melão e pepino, e uma menor virulência em abóbora. Em trabalho visando encontrar hospedeiros de C. lagenarium em cucurbitáceas, Rego et al. (1995b) identificaram duas espécies de abóbora resistentes ao fungo, evidenciando que este gênero possui fontes de resistência a C. lagenarium. Não se observam relatos sobre a identificação de fontes de resistência em pepino e melão a C. lagenarium (Rego et al., 1995a; Goode, 1958; Winstead et al., 
1959), mesmo estas cucurbitáceas apresentando alta diversidade genética (Clark et al., 1991).

Não foi encontrada correspondência entre a virulência do isolado e o hospedeiro, o local de coleta, suas características culturais ou morfológicas. Cada isolado apresentou um comportamento diferente perante os demais, quando se considerou a gama de hospedeiros à ele suscetíveis. Rego et al., (1994) também não encontraram correspondência entre a virulência e o hospedeiro, e o local da coleta de isolados de melancia, no entanto Wasilwa et al. (1993) observaram correspondência entre a origem, o grupo de compatibilidade vegetativa e a virulência de isolados de pepino, melão, melancia e abóbora. Furtado et al. (1999) obtiveram correlação com os conídios mais ovalados de C. gloeosporioides que não foram patogênicos a discos de folíolos de seringueira, no entanto Sanders \& Korsten (2003) não observaram correlação entre as dimensões dos conídios de C. gloeosporioides e a virulência dos isolados quando inoculados em manga e abacate, assim como Assis et al. (2001) que não constataram correlação entre as características culturais de isolados de C. gloeosporioides e a virulência dos mesmos em manga. Silva-Mann et al. (2001) trabalhando com o complexo Colletotrichum associado a sementes de algodoeiro, não encontraram total similaridade dos resultados de patogenicidade com os resultados das características morfológicas dos isolados, porém discutem a possibilidade do cultivar utilizado nos testes de patogenicidade apresentar algum tipo de resistência, o que teria influenciado os resultados na avaliação da patogenicidade.

Devido o comportamento diferenciado dos isolados, e ao reduzido número de isolados virulentos encontrados, não foi possível detectar biótipos especializados a um hospedeiro, como foi possível no trabalho de Hayden et al. (1994). Normalmente, espécies distintas de plantas são utilizadas para identificação de formas especiais em patógenos, entretanto este tipo de especialização não parece existir em C. lagenarium (Rego et al., 1995a). Talvez com um maior número de isolados e um número maior de variedades e de hospedeiros, se possa identificar tal especialização. 
Da mesma forma que cada isolado se comportou distintamente perante aos demais quanto à virulência, na avaliação do período de incubação, período latente e índice de crescimento de lesão, estes também se apresentaram diferentes entre si, além de não haver correlação entre os três fatores avaliados.

O período de incubação, da inoculação ao surgimento de sintomas, variou em média de dois a sete dias (Tabela 10). As lesões resultantes apresentaram formato circular a elíptico, e coloração que variou de castanho a marrom escura. Lesões marrom escuras foram encontradas associadas a cotilédones de melancia, semelhante às descritas por Wasilwa et al. (1993), e lesões castanho associadas à folhas de chuchu e cotilédones de melão, pepino e abóbora. Os períodos de incubação se encontraram dentro do relatado em trabalhos com C. lagenarium, variando de três a seis dias (Wasilwa et al.,1993; Shen et al., 2001; Rego et al., 1994). De um modo geral, os isolados de pepino apresentaram menores períodos de incubação em plântulas de melancia e melão, do que em seu hospedeiro de origem. Os isolados de melancia e abóbora apresentaram períodos de incubação próximos para plântulas de pepino, melão e melancia, com exceção do isolado MA3 que apresentou entre estes o maior período de incubação.

Observa-se nas plântulas de abóbora e chuchu que, além de se apresentarem suscetíveis a um menor número de isolados, o desenvolvimento da lesão nas mesmas é retardado e mais lento, com os maiores períodos de incubação e menores índices de crescimento de lesão.

O período latente para a maioria dos isolados se apresentou dentro do esperado, com esporulação do fungo durante os primeiros estádios de desenvolvimento de lesão, como reportado por Thompson \& Jenkins (1985). A média de dias após o surgimento do sintoma para a esporulação foi de aproximadamente 1,06 dias, sendo que muitas lesões quando foram constatadas já exibiam esporulação. Na maioria das lesões esporulantes, foi possível observar a formação de massa conidial de cor laranja, semelhante à produzida pelos isolados em meio de cultura.

O índice de crescimento micelial serviu para acompanhar a evolução da lesão e a velocidade em que esta ocorre. Assim, podemos considerar que os isolados que apresentaram os maiores índices de crescimento micelial foram mais agressivos, pois 
rapidamente a lesão tomou a superfície do cotilédone ou folha inoculados. Observa-se que o isolado ME2 apresentou o maior índice de crescimento de lesão, apresentando também o maior índice de crescimento micelial, no entanto o isolado MA1 apresentou um dos menores índices de crescimento micelial em meios de cultura, mas seu índice de crescimento de lesão foi maior que $70 \%$ dos isolados. Apesar de não se encontrar correlação entre os resultados, o índice de crescimento de lesão apresenta-se maior nos isolados que apresentam um menor período de incubação.

Tabela 10. Período de incubação, período latente, e índice de crescimento de lesão de isolados de C. lagenarium

\begin{tabular}{lcccccccccccccccc}
\hline \multirow{2}{*}{ Isolados } & \multicolumn{4}{c}{ Incubação $^{1}$} & \multicolumn{1}{c}{ Latência $^{2}$} & \multicolumn{1}{c}{ I.C.L } \\
& pe & me & ma & ab & ch & pe & me & ma & ab & ch & pe & me & ma & ab & ch \\
\hline CH1 & - & - & - & - & 5,0 & - & - & - & - & 9,0 & - & - & - & - & 3,0 \\
CL5 & 4,0 & 3,0 & 2,0 & - & - & 5,0 & 3,0 & 3,0 & - & - & 2,8 & 3,0 & 3,5 & - & - \\
CL15 & 7,0 & 5,0 & - & - & - & 5,0 & 5,0 & - & - & - & 1,6 & 3,0 & - & - & - \\
CL20 & - & - & 2,0 & - & - & - & - & 6,0 & - & - & - & - & 1,5 & - & - \\
CL22 & 7,0 & 5,0 & - & - & - & 7,0 & 6,0 & - & - & - & 1,4 & 1,8 & - & - & - \\
AB1 & 4,0 & 3,0 & 3,0 & 7,0 & - & 4,0 & 5,0 & 4,0 & 7,0 & - & 0,6 & 1,0 & 0,8 & 0,5 & - \\
AB2 & - & 3,0 & - & 7,0 & - & - & 4,0 & - & 7,0 & - & - & 0,9 & - & 0,5 & - \\
AB3 & - & 3,0 & 6,0 & - & 6,0 & - & 3,0 & 6,0 & - & 7,0 & - & 2,8 & 1,5 & - & 1,0 \\
MA1 & 4,0 & 4,0 & 5,0 & - & 6,0 & 5,0 & 4,0 & 5,0 & - & 7,0 & 2,0 & 3,0 & 2,3 & - & 1,1 \\
MA2 & 4,0 & 3,0 & 4,0 & - & - & 5,0 & 4,0 & 4,0 & - & - & 1,2 & 1,5 & 2,0 & - & - \\
MA3 & 7,0 & - & - & - & - & 7,5 & - & - & - & - & 1,0 & - & - & - & - \\
ME1 & 5,0 & 5,0 & - & - & - & 5,0 & 6,0 & - & - & - & 1,4 & 0,8 & - & - & - \\
ME2 & 2,0 & 3,0 & 2,0 & 2,0 & - & 3,0 & 4,0 & 3,0 & 3,0 & - & 5,6 & 4,0 & 4,8 & 5,2 & - \\
ME3 & - & 4,7 & - & - & - & - & 7,0 & - & - & - & - & 0,5 & - & - & -
\end{tabular}

1 - dias da inoculação até aparecimento do sintoma; 2 - dias da inoculação até a esporulação; 3 - índice de crescimento de lesão (mm/dia); pe - pepino; me - melão; ma - melancia; ab - abóbora; ch - chuchu. Médias seguidas pela mesma letra na coluna não diferem entre si, pelo teste de Tukey, a 5\% de probabilidade.

Observa-se que não há uma uniformidade dos resultados dos períodos de incubação e latência quando se analisa isolados de um mesmo hospedeiro, no entanto entre os hospedeiros testados, para a maioria dos isolados as plântulas de pepino, melancia e melão apresentam desenvolvimento de sintomas mais rápido que as plântulas de abóbora, e plantas de chuchu. A única exceção ocorre quando inoculado o isolado 
ME2, que apresenta o mesmo comportamento para praticamente todas plântulas inoculadas, com períodos de incubação e latente curtos, e um elevado índice de crescimento de lesão, chegando a necrosar por completo a plântula durante um curto período.

Os resultados de patogenicidade, caracterização cultural e caracterização morfológica não foram suficientes para caracterizar completamente os isolados de $C$. lagenarium. Resultados semelhantes foram encontrados por Furtado et al. (1999), ao avaliarem isolados de C. gloeosporioides isolados de diferentes tecidos de seringueira. A impossibilidade de se agrupar os isolados segundo as características analisadas poderia ser decorrente da alta variabilidade apresentada pelos isolados para estas características, e/ou o pequeno número de isolados utilizados neste estudo.

\subsubsection{Identificação molecular}

\subsubsection{Extração de DNA}

O DNA genômico dos 25 isolados de C. lagenarium foi obtido através do protocolo aprimorado de extração de Martins \& Bacci Júnior (2001), quantificado e verificada sua qualidade conforme descrito por Sambrook et al.(1989). A quantidade de DNA obtida da extração foi suficiente para realização dos demais procedimentos moleculares, contudo a qualidade do DNA não se apresentou muito próxima do ideal, com razões das O.D. 260/280 variando entre 1,4 e 1,7, enquanto que o ideal seria estarem entre 1,8 e 2,0, contudo não impossibilitaram a execução do trabalho.

\subsubsection{Reação de PCR}

A reação de PCR utilizada para amplificação da região ITS apresentou resultados positivos, ou seja, visualização de bandas de aproximadamente 600 pares de bases, para todos os isolados testados. No entanto, na reação de PCR que utilizou os "primers" CoINT e ITS4, apenas os isolados CH3, PE4, AB274, ME1 e ME2 apresentaram 
bandas, também com aproximadamente 600 pares de bases, os demais isolados, virulentos ou não nos testes de inoculação cruzada, não apresentaram bandas com a utilização dos “primers” CoINT e ITS4 (Figura 1 e 2). Também não apresentou banda o isolado de C. gloeosporioides, utilizado como controle negativo. O reconhecimento de apenas 5 isolados sugere que possa haver uma especificidade muito grande do "primer" CoINT, não possibilitando reconhecer os demais isolados, ou que haja variabilidade genética entre as espécies de C. lagenarium na região ITS1, região seqüenciada de onde o "primer" CoINT foi desenhado. Durante o trabalho não houve a possibilidade de utilização de outros métodos moleculares para melhor identificação e caracterização molecular, no entanto são conhecidos outros métodos como seqüenciamento do material genético, ou caracterização com utilização de marcadores moleculares, que vêm apresentando bons resultados em estudos com o gênero Colletotrichum (Cannon et al. 2000; Menezes, 2002).

Os isolados que apresentaram bandas com a utilização de “primer” específico para C. lagenarium não apresentam características culturais, morfológicas ou patogênicas comuns entre si, apenas os isolados ME1 e ME2 que são oriundos da mesma espécie hospedeira (Capítulo 3 e 4). Da mesma forma, os isolados que não apresentaram reação positiva com o “primer” CoINT, não apresentam características comuns entre si, e diferentes dos demais, que pudesse explicar os resultados obtidos.

Observa-se que as amostras das reações, no gel de agarose colorido e fotografado, apresentam características de degradação do produto da reação (Figura 1). Contudo, as reações foram realizadas repetidas vezes, e mesmo quando não se observou degradação do produto da reação, os isolados que não apresentaram reação positiva, continuavam não apresentando bandas. 


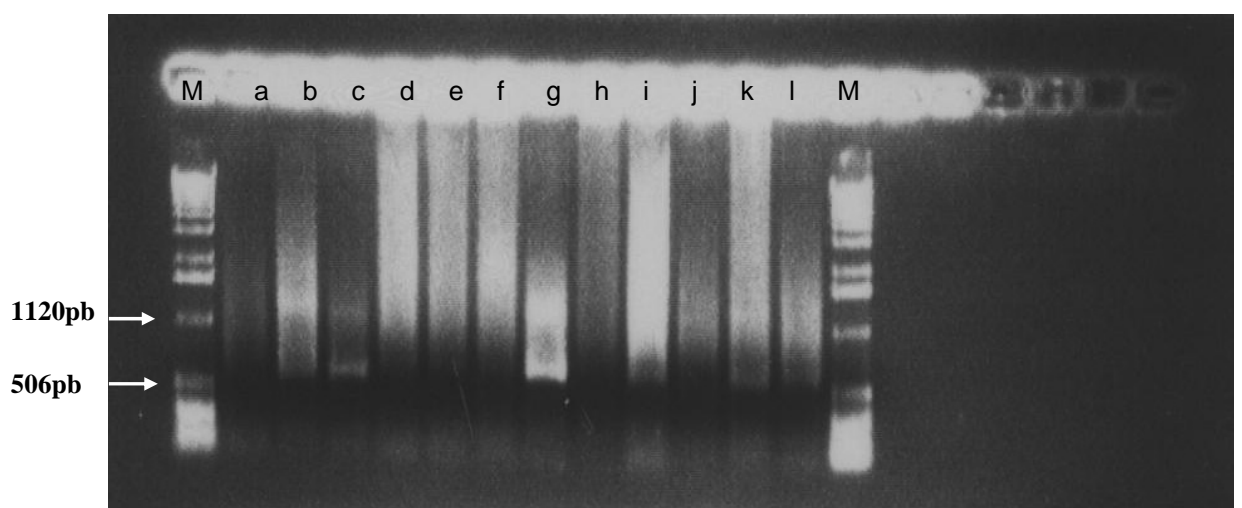

Figura 1-Produtos da PCR de 12 isolados de C. lagenarium, com o par de "primers" CoINT-ITS4 (M-marcador 1Kb; a-CH1; b-CH3; c-CH4; d-CL5; e-CL7; f-CL22; g-PE3; h-PE4; i-AB2; j-MA1; k-MA3; l-ME3)

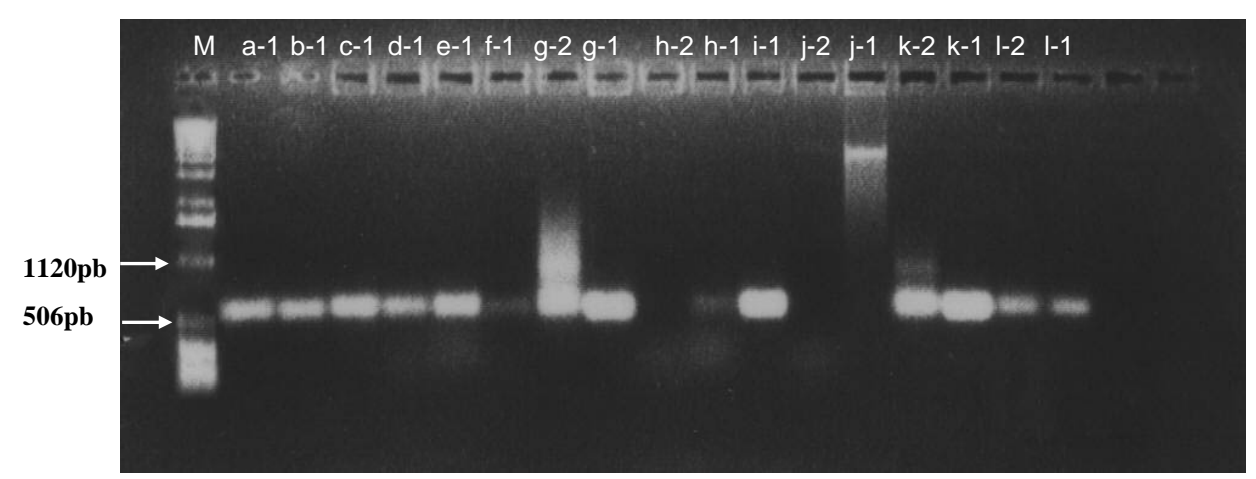

Figura 2-Produtos da PCR de 15 isolados de C. lagenarium, com os pares de "primers" ITS4-ITS5 (_-1) e CoINT-ITS4 (_-2) (M-marcador 1Kb; a-CH4, b-PE1, c-PE3, d-PE4, e-PE5, f-CL5, g-AB274, h-AB1, i-AB2, j-AB3, k-ME1, l-ME2)

\section{Conclusões}

Isolados provenientes de um determinado hospedeiro podem infectar outras espécies de cucurbitáceas.

A variabilidade observada na virulência dos isolados impede o agrupamento dos mesmos durante com base na gama de hospedeiros.

A ferramenta molecular PCR foi capaz de identificar isolados da espécies $C$. lagenarium a partir do produto amplificado da região ITS dos mesmos. No entanto, nem 
todos os isolados foram identificados dessa maneira, sugerindo que essa espécie apresenta variabilidade na região amplificada pelo “primer” CoINT. 


\section{CONCLUSÕES GERAIS}

O meio de Aveia contribuiu com melhores respostas de crescimento micelial e esporulação.

O crescimento micelial, diferente da esporulação, apresenta resultados reprodutíveis variando-se o meio de cultura, no entanto ambos apresentam variação quando se analisam os resultados entre os isolados.

As características culturais, com exceção da coloração da massa conidial, apresentaram grande variabilidade, inviabilizando a identificação da espécie.

A maioria dos isolados apresentou conídios e apressórios com formatos e dimensões dentro do esperado para a espécie. Alguns isolados que apresentaram dimensões inferiores, e poderiam ser identificados como C. gloeosporioides devido à proximidade de características. Contudo, as características morfológicas não se apresentaram como bons parâmetros para identificação da espécie C. lagenarium.

Isolados provenientes de um determinado hospedeiro podem infectar outras espécies de cucurbitáceas.

A variabilidade observada na virulência dos isolados impede o agrupamento dos mesmos com base na gama de hospedeiros.

A ferramenta molecular PCR foi capaz de identificar isolados da espécies $C$. lagenarium a partir do produto amplificado da região ITS dos mesmos. No entanto, nem todos os isolados foram identificados dessa maneira, sugerindo que essa espécie apresenta variabilidade na região amplificada pelo "primer” CoINT. 


\section{REFERÊNCIAS BIBLIOGRÁFICAS}

AGRIOS, G.N. Plant Pathology. 4.ed. New York: Academic Press. 1997. 635p.

ALAHAKOON, P.D.; BROWN, A.E.; SREENIVASAPRASAD, S. Crossinfection potential of genetic groups of Colletotrichum gloeosporioides on tropical fruits. Physiological and Molecular Plant Pathology, v. 44, n. 2, p. 93-103, 1994.

ALEXOPOULOS, C.J.; MIMS, C.W.; BLACKWELL, M. Introductory Mycology. 4.ed. New York: Editora John Wiley \& Sons. 1996. 868p.

ALZATE-MARIN, A.L.; BAÍA, G.S.; FALEIRO, F.G.; CARVALHO, G.A.; PAULA JR., T.J.; MOREIRA, M. A.; BARROS, E.G. Análise da diversidade genética de raças de Colletotrichum lindemuthianum que ocorrem em algumas regiões do Brasil por marcadores RAPD. Fitopatologia Brasileira, v. 22, n. 1, p. 85-88, 1997.

ARTIGIANI FILHO, V.H.; BEDENDO, I.P. Variabilidade de Helminthosporium oryzae detectada através da ocorrência de setores na colônia, sensibilidade a fungicidas, crescimento em diferentes meios de cultura e temperatura de incubação. Summa Phytopathologica, v. 22, n. 3, p. 217-221, 1996. 
ASSIS, T.C.; MENEZES, M.; ANDRADE, D.E.G.T.; COELHO, R.S.B.; OLIVEIRA, S.M.A. Estudo comparativo de isolados de Colletotrichum gloeosporioides quanto ao efeito da nutrição de carboidratos no crescimento, esporulação e patogenicidade em frutos de três variedades de mangueira. Summa Phytopathologica, v. 27, n. 2, p. 208-212, 2001.

BACH, E.E.; KIMATI, H. Análise serológica e eletroforética de Exserohilum turcicum, isolado de milho, sorgo e capim massambará. Summa Phytopathologica, v. 21, n.2, p. 140-146, 1995 a.

BACH, E.E.; KIMATI, H. Comparação morfológica e patogênica de Exserohilum turcicum, isolado de milho, sorgo e capim massambará. Summa Phytopathologica, v. 21, n. 2, p. 134-139, 1995 b.

BADEL, J.L.; KELEMU, S. Variación en crecimiento, esporulación y sensibilidad a benlate de aislamientos suramericanos de Colletotrichum gloeosporioides. Pasturas Tropicales, v. 19, n. 1, p. 2-9, 1997.

BAILEY, F.A.; JERGER, M.L. Colletotrichum: biology, pathology and control. Wallingford, CAB International, 1992. 388p.

BAILEY, J.A.; NASH, C.; MORGAN, L.W.; O’CONNELL, R.J.; TEBEEST, D.O. Molecular taxonomy of Colletotrichum species causing anthracnose on the Malvaceae. Phytopathology. v. 86, n.10, p. 1076-1083, 1996.

BAXTER, A.P.; Van der WESTHUIZEN, G.C.A.; EICKER, A. Morphology and taxonomy of South African isolates of Colletotrichum. South African Journal of Botany. v. 2, p. 259-289, 1983. 
BERNSTEIN, B.; ZEHR, E.I.; DEAN, R.A.; SHABI, E. Characteristics of Colletotrichum from peach, apple, pecan and other hosts. Plant Disease, v. 79, n.5, p. 478-482, 1995.

BRAITHWAITE, K.S.; IRWIN, J.A.G.; MANNERS, J.M. Restriction fragment length polymorphism in Colletotrichum gloeosporioides infecting Stylosanthes spp. In Australia. Mycological Research, v. 94, n. 8, p. 11291137, 1990.

BROWNING, M.; ROWLEY, L.V.; ZENG, P.; CHANDLEE, J.M.; JACKSON, N. Morphological, pathogenic, and genetic comparisons of Colletotrichum graminicola isolates from Poaceae. Plant Disease, v. 83, n. 3, p. 286-292, 1999.

CANNON, P.F.; BRIDGE, P.D.; MONTE, E. Linking the past, present and future of Colletotrichum systematics. In: PRUSKY, D.; FREEMAN, S.; DICKMAN, M.B. Colletotrichum: host specificity, pathology, and host-pathogen interaction. v. 1, p.1-20, 2000.

CARVALHO, F.M.S.; LEITE JR., R.P.; UENO, B. Pathogenic characterization of Colletotrichum spp. associated with apple diseases in southern Brazil. Fitopatologia Brasileira, v. 25, n. 1, p. 72-78, 2000.

CLARK, R.L.; WIDRLECHNER, M.P.; REITSMA, K.R.; BLOCK, C.C. Cucurbit germplasm of the North Central Regional Plant Introduction Station, Ames, Iowa. HortScience, v. 26, n.4, p. 450-451, 1991.

COCHRANE, V.W. Physiology of fungi. New York: John Wiley, 1958. 524p. 
CORRELL, J.C.; RHOADS, D.D.; GEUBER, J.C. Examination of mitochondrial DNA restriction length polymorphisms, DNA fingerprints, and randomly amplified polymorphic DNA of Colletotrichum orbiculare. Phytopathology, v. 83, n. 11, p.1199-1204. 1993.

$=-$

COUTO, E.F.; MENEZES, M. Caracterização fisiomorfológica de isolados de Colletotrichum musae. Fitopatologia brasileira. v. 29, n. 4, p. 406-412, 2004.

DEISING, H.B.; WERNER, S; WERNITZ, M. The role of fungal apressoria in plant infection. Microbes and infection, v. 2, n. 13, p. 1361-1641, 2000.

FERRAZ, J.F.P. Morfologia, comportamento cultural e patogenicidade de espécies de Colletotrichum e Gloeosporium. Agronomia Lusitana, v. 38, n. 1, p. 163-179, 1977.

FIGUEIREDO, G.; ALFENAS, A.C.; BROMMONSCHENKEL, S.H.; FARIA, J.C. Variabilidade isoenzimática de isolados de Colletotrichum lindemuthianum com diferentes níveis de virulência. Arquivos de Biologia e Tecnologia, v. 36, n. 4, p.793-808, 1993.

FREEMAN, S.; KATAN, T.; SHABI, E. Characterization of Colletotrichum gloeosporioides isolates from avocado and almond fruits with molecular and pathognicity tests. Applied and Environmental Microbiology, v. 62, n. 3, p.1014-1020, 1996. 
FURTADO, E.L.; BACH, E.E.; KIMATI, H.; MENTEN, J.O.M.; SILVEIRA, J.A. Caracterização morfológica, patogênica e isoenzimática de isolados de Colletotrichum gloeosporioides de seringueira. Summa Phytopathologica, v. 25, n. 3, p. 222-228, 1999.

GOES, A., KIMATI, H. Caracterização morfológica de isolados de Colletotrichum acutatum e Colletotrichum gloeosporioides associados à queda prematura de frutos cítricos. Summa Phytopathologica, v. 23, n. 1, p. 4-10, 1997a.

GOES, A., KIMATI, H. Caracterização patogênica de isolados de Colletotrichum acutatum e Colletotrichum gloeosporioides, obtidos de plantas cítricas. Summa Phytopathologica, v. 23, n. 1, p. 10-14, 1997b.

GOODE, M.J. Physiological specialization in Colletotrichum lagenarium. Phytopathology, v. 48, n. 1, p. 79-83, 1958.

GRIFFIN, D.H. Fungal Physiology. 2 ed., New York: Willey-Liss, 1994. 458p.

GUTHRIE, P.A.I.; MAGILL, C.W.; FREDERIKSEN, R.A.; ODVODY, G.N. Random amplified polymorphic DNA markers: a system for identifying and differentiate isolates of Colletotrichum graminicola. Phytopathology, v. 82, n. 8, p. 832-835, 1992.

HAYDEN, H.L.; PEGG, K.G.; AITKEN, E.A.B.; IRWIN, J.A.G. Genetic relationships as assessed by molecular markers and cross-infection among strains of Colletotrichum gloeosporioides. Australian Journal of Botany, v. 42, n. 1, p. 9-18, 1994. 
KELEMU, S.; SKINNER, D.Z.; BADEL, J.L.; MORENO, C.X.; RODRIGUEZ, M.X.; FERNANDES, C.D.; CHARCHAR, M.J.; CHAKRABORTY, S. Genetic diversity in South American Colletotrichum gloeosporioides isolates from Stylosanthes guianensis, a tropical forage legume. European Journal of Plant Pathology, v. 105, n. 3, p. 261-272, 1999.

KUBO, Y.; SUZUKI, K.; FURUSAWA, I.; ISHIDA, N.; YAMAMOTO, M. Relation of appressorium pigmentation and penetration on nitrocellulose membranes by Colletotrichum lagenarium. Phytopathology, v. 72, n.5, p. 498-501, 1982.

KURAMAE-IZIOKA, E.E; LOPES, C.R.; SOUZA, N.L.; MACHADO, M.A. Morphological and molecular characterization of Colletotrichum spp. From citrus orchards affected by postbloom fruit drop in Brazil. European Journal of Plant Pathology, v. 103, n. 4, p. 323-329, 1997.

KUROZAWA, C.; PAVAN, M.A. Doenças das cucurbitáceas. In: KIMATI, H.; AMORIN, L.; BERGAMIN FILHO, A.; CAMARGO, L.E.A.; REZENDE, J.A.M. Manual de fitopatologia. São Paulo: Editora Agronômica Ceres, 1997. c. 29, p.325-337: Doenças das plantas cultivadas.

LIMA FILHO, R. M.; OLIVEIRA, S.M.A.; MENEZES, M. Caracterização enzimática e patogenicidade cruzada de Colletotrichum spp. associados a doenças de pós-colheita. Fitopatologia Brasileira, v. 28, n. 6, p. 620-625, 2003.

LISBOA, A. Cultura da Bucha. 2.ed. Serviço de Informação Agrícola. Ministério da Agricultura. Rio de Janeiro, 1962. 36p. 
LIYANAGE, H.D.; McMILLAN, R.T.Junior; KISTLER,H.C. Two genetically distinct populations of Colletotrichum gloeosporioides from citrus. Phytopathology, v. 82, n.11, p. 1371-1376, 1992.

MARTINS, V.G.; BACCI Júnior, M. Métodos moleculares para o estudo do DNA: I-Extração e amplificação de DNA. Rio Claro: UNESP - Centro de Estudos de Insetos Sociais, 2001.10p.

MENEZES, M. Aspectos biológicos e taxonômicos de espécies do gênero Colletotrichum. Fitopatologia Brasileira, v.27 (supl.), p.23-24, 2002.

MESQUITA, A.G.G.; FALEIRO, F.G.; PAULA Júnior, T.J.; RAGAGNIN, V.A.; MOREIRA, M.A.; BARROS, E.G. Use of molecular markers to differentiate Colletotrichum lindemuthianum races 89 and 69. Fitopatologia Brasileira, v. 23, n.1, p. 58-61, 1998.

MILLS, P.R.; HODSON, A.; BROWN, A.E. Molecular differentiation of Colletotrichum gloeosporioides isolates infecting tropical crops. In: BAILEY, J.A.; JERGER, M.J. (Ed.). Colletotrichum: biology, pathology and control. Wallingford, U.K.: CAB International, p.269-288, 1992.

MILLS, P.R.; SREENIVASAPRESAD, S.; BROWN, A.E. Detection of the anthracnose pathogen Colletotrichum.In: SHOTS, A.; DEWEY, F.M.; OLIVER, R.P.(eds) Modern assay for plant pathogenic fungi: identification, detection and quantification. Oxford: CAB International, 1994. p.183-189. 
Minas Gerais. Secretaria do Estado da Agricultura, Pecuária e Abastecimento. Cenário futuro para cadeia produtiva de olerícolas em Minas Gerais. Belo Horizonte: EMATER/MG, 1995. v.12.

MUNIS, M.F.S.; SANTOS, R.C.R.; BARBOSA, G.V.S. Patogenicidade de isolados de Colletotrichum gloeosporioides sobre algumas frutíferas. Summa Phytopathologican, v. 24, n. 2, p. 177-179, 1998.

PERES, N.A.R.; KURAMAE, E.E.; DIAS, M.S.C.; SOUZA, N.L.de; Identification and characterization of Colletotrichum spp. affecting fruit after harvest in Brazil. Journal of Phytopathology, v. 150, n. 3, p. 128-134, 2002.

QUEIROZ, M. A. de. Potencial do germoplasma de cucurbitáceas no nordeste brasileiro. Horticultura Brasileira, v. 11, n. 1, p. 7-9, 1993.

REGO, A.M.; MAFFIA, A.L.; ALFENAS, A.C.Virulência e análise de isoenzimas de Colletotrichum orbiculare. Fitopatologia Brasileira, v. 19, n. 4, p. 552-559, 1994.

REGO, A.M.; MAFFIA, L.A.; ALFENAS,A.C. Reação de germoplasma de melancia (Citrullus lanatus) e melão (Cucumis melo) a Colletotrichum orbiculare. Fitopatologia Brasileira, v. 20, n. 1, p. 48-55, 1995a.

REGO, A.M.; MAFFIA, L.A.; ALFENAS,A.C. Espécies de Cucurbitaceae como hospedeiras de Colletotrichum orbiculare. Fitopatologia Brasileira, v. 20, n. 1, p.56-59, $1995 b$. 
SAMBROOK, J.; FRITSCH, E.F.; MANIATIS, T. Molecular Cloning: a Laboratory Manual. 2.ed. New York: Cold Spring Harbor Laboratory Press,1989. v.1-2.

SANDERS, G.M.; KORSTEN, L.; A comparative morphological study of South African avocado and mango isolates of Colletotrichum gloeosporioides. Canadian Journal of Botany, v. 81, n. 8, p. 877-885, 2003.

SHEN, S.; GOODWIN, P.H.; HSIANG, T. Infection of Nicotiana species by the anthracnose fungus, Colletotrichum lagenarium. European journal of Plant Pathology, v. 107, n. 8, p. 767-773, 2001.

SHERRIFF, C.; WHELAN, M.J.; ARNOLD, G.M.; LAFAY, J.M.; BRYGOO, J.; BAILEY, J.A. Ribosomal DNA sequence analysis reveals new species groupings in the genus Colletotrichum. Experimental Mycology, v. 18, n. 2, p.121-138, 1994.

SILVA-MANN, R.; SALGADO, K.C.C.; VIEIRA, M.G.G.C.; MACHADO, J.C. Variabilidade genética de isolados do complexo Colletotrichum associados a sementes de algodoeiro, por meio de técnicas moleculares e inoculação em plântulas. Fitopatologia Brasileira, v. 27, n. 1, p. 27-32, 2002.

SIMMONDS, J.H. A study of the species of Colletotrichum causing ripe fruit rots in Queensland. Journal of Agriculture and Animal Science, v. 22, p. 437-459, 1965. 
SITTERLY, R.W.; KEINATH, A.P. Anthracnose. In: ZITTER, T.A.; HOPKINS, D.L.; THOMAS, C.E. (Ed.). Compendium of cucurbit diseaes. St. Paul: APS Press, p.24-25, 1996.

SREENIVASAPRASAD, S.; MILLS, P.R.; MEEHAN, B.M.; BROWN, A.E. Phylogeny and sistematics of 18 Colletotrichum species based on ribosomal DNA spacer sequences. Genome, v. 39, n. 3, p. 499-512, 1996.

SUTTON. B.C. 1980. The Coelomycetes. Surrey, England: Commonwelth Mycological Institute.1980. 696p.

SUTTON, B.C. The genus Glomerella and it's anamorph Colletotrichum. In: BAILEY, J.A.; JERGER, M.J. (Ed.). Colletotrichum: biology, pathology and control. Wallingford, U.K.: CAB International, p. 1-26, 1992.

TANDON, R.N.; CHANDRA, S. The nutrition of Colletotrichum gloeosporioides Penz. Mycopathology. v. 18, n. 10, p. 213-224, 1962.

THOMPSON, D.C.; JENKINS, S.F. Influence of cultivar resistance, initial disease, environment, and fungicide concentration and timing on anthracnose development and yield loss in pickling cucumbers. Phytopathology, v. 75, n.12, p. 1422-1427, 1985.

TIMNICK, M.B.; LILLY, V.G.; BARNETT, H.L. Factors affecting sporulation of Diaporthe phaseolorum var. batatais from soybean. Phytopathology, v. 41, n.4, p.327-336, 1951. 
TUITE, J. Plant Pathological Methods: Fungi and Bacteria. Minneapolis: Burgess Publishing, 1969. 239p.

VERAS, S.M.; GASPAROTTO, L.; MENEZES, M. Variabilidade fisiomorfológica de Colletotrichum graminicola em diferentes substratos. Arquivos de Biologia e Tecnologia, v. 40, n. 2, p. 297-305, 1997.

VILARINHOS, A.D.; PAULA Júnior, T. J.; BARROS, E.G.; MOREIRA, M.A. Characterization of races of Colletotrichum lindemuthianum by the random amplified polymorphic DNA technique. Fitopatologia Brasileira, v. 20, n. 2, p.195-198, 1995.

VINNERE, O. Approaches to species delineation in anamorphic (mitosporic) fungi: a study on two extreme cases. Uppsala-Suécia, 2004. 72p. Tese (Doutorado) - Faculty of Science and Technology.

WASILWA, L.A.; CORRELL, J.C.; MORELOCK, T.E.; McNEW, R.E. Reexamination of races of the cucurbit anthracnose pathogen Colletotrichum orbiculare. Phytopathology, v.83, n. 11, p. 1190-1198, 1993.

WHITE, T.J.; BRUNS, T., LEE, S.;TAYLOR, J.W. Amplification and direct sequencing of fungal ribosomal RNA genes for phylogenetics. In: INNIS, M.A.; GELFAND, D.H.; SNINSKY, J.J.;WHITE, T.J. (Ed.) PCR Protocols: A Guide to Methods and Applications. San Diego: Academic Press, 1990. p. 315-322. 
WILLIANS, J.G.K.; KUBELIK, A.R.; LIVAK, J.K.; RAFALSKI, J.A.; TINGEY, S.W.V. DNA polymorphisms amplified by arbitrary primers are useful as genetic markers. Nucleic Acid Research. v. 18, n. 1, p. 6531-6535, 1990.

WINSTEAD, N.N.; GOODE, M.J.; BARHAM, W.S. Resistance in watermelon to Colletotrichum lagenarium races 1, 2 and 3. Plant Disease Reporter, v. 43, n. 7, p.570-577, 1959. 